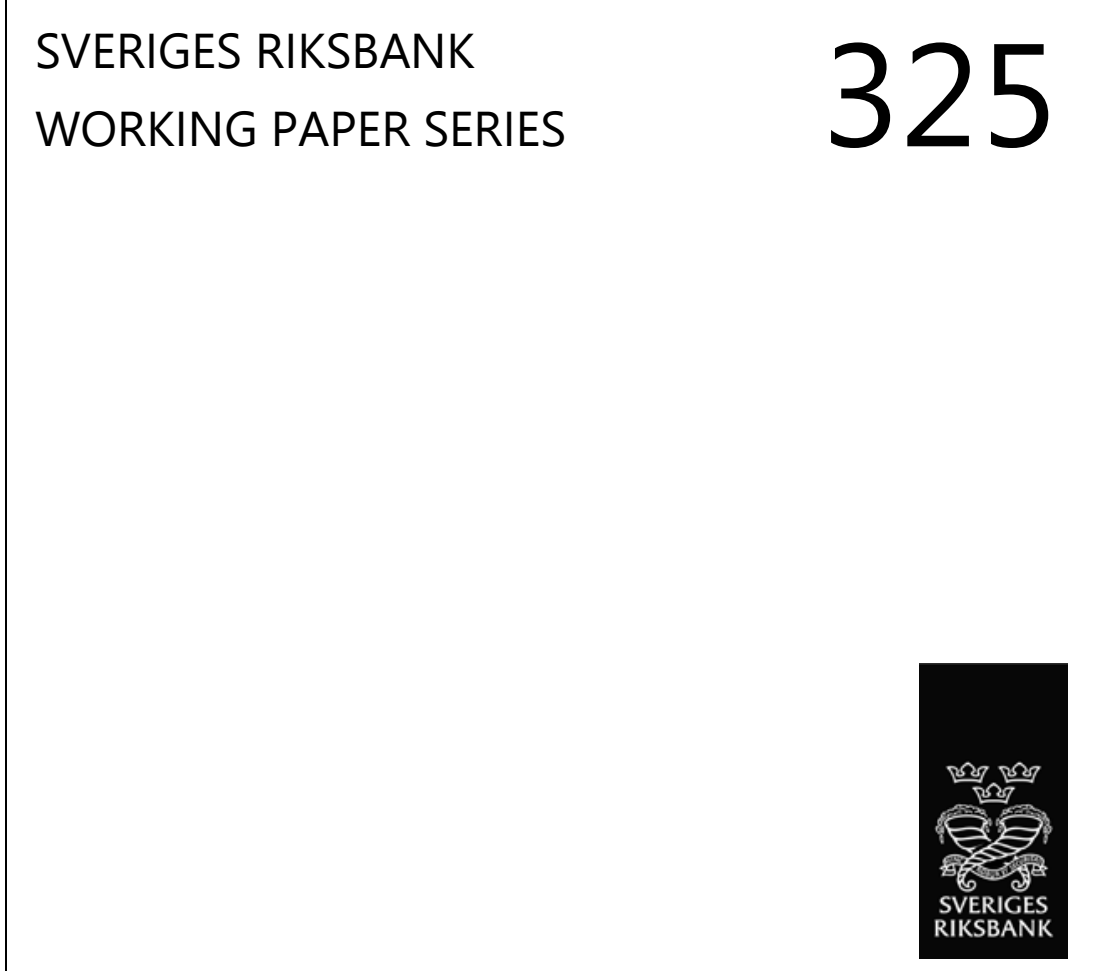

\title{
COVENANT-LIGHT \\ CONTRACTS AND CREDITOR COORDINATION
}

Bo Becker and Victoria Ivashina

May 2016 


\section{WORKING PAPERS ARE OBTAINABLE FROM}

www.riksbank.se/en/research

Sveriges Riksbank $\cdot$ SE-103 37 Stockholm

Fax international: +468210531

Telephone international: +4687870000

The Working Paper series presents reports on matters in the sphere of activities of the Riksbank that are considered to be of interest to a wider public.

The papers are to be regarded as reports on ongoing studies and the authors will be pleased to receive comments.

The opinions expressed in this article are the sole responsibility of the author(s) and should not be interpreted as reflecting the views of Sveriges Riksbank. 


\title{
Covenant-light Contracts AND Creditor CoORdination
}

\author{
Bo Becker* \\ Stockholm School of Economics \\ Victoria Ivashina* \\ Harvard University and NBER \\ Sveriges Riksbank Working Paper Series \\ No. 325
}

May 2016

In 2015, 70\% of newly-issued leveraged loans had weaker enforcement features, called covenantlight or "cov-lite;" this is nearly a three-time increase in cov-lite issuance compared to a previous peak in 2007. We evaluate whether this development can be attributed to market overheating, increased borrower demand for cov-lite loans, or a rise in creditor coordination costs. The last hypothesis stems from the increasing involvement of non-bank institutions and, in particular, the rise of mutual fund participation in the leveraged loan market after the financial crisis. Based on the wider syndication, (narrower) skills, and diverse incentives of non-bank institutional lenders, optimal contracts between them and corporate borrowers likely involve fewer monitoring tools and weaker control rights. We evaluate these explanations of cov-lite contract provisions in a large sample of U.S. loans for the 2001-2014 period. Consistent with creditor-driven explanations for cov-lite issuance, we show that cov-lite prices compress as the prevalence of cov-lite rises. Time patterns in cov-lite issuance closely match inflows to institutional lenders, and at a given time, cov-lite loans are, overwhelmingly, those with the highest ownership by structured products and/or mutual funds. The number and share of structured products and mutual funds also impact the propensity toward other contractual features that influence when and how creditors have control. However, these factors are less relevant in explaining the strength of restrictions on indebtedness, liens, payments, or assets sales.

Keywords: Credit cycles; Loan contracts; Debt Covenants.

JEL Codes: G11, G22, G30

\footnotetext{
* Stockholm School of Economics, and Harvard and NBER, respectively. The opinions expressed in this article are the sole responsibility of the author(s) and should not be interpreted as reflecting the views of Sveriges Riksbank. We are grateful to Jennifer Dlugosz (discussant), Chris Malloy, Giovani Olivei, Mariassunta Giannetti and Jeremy Stein as well as seminar participants at the AEA, Boston Federal Reserve Bank, Einaudi, Sveriges Riksbank, NHH, Nanyang Technical University, Brandeis University, Harvard Business School, Yale University and Rice University for comments and suggestions. We thank Lampros Baltas and Canli Hua for excellent research support.
} 
The allocation of control between firms and their investors is a key dimension of financial contracting. In corporate credit markets, the division of control is mainly decided by covenants, conditions on borrower behavior that are written into the loan contract. In one of the largest shifts to date in the use of contracts to protect creditor interests, a significant amount of recent corporate loan issuance has been "cov-lite". Contrary to what their name might suggest, cov-lite loans do not have fewer covenants. What differentiates these loans and makes them riskier is weaker covenant enforcement. A cov-lite contract (equivalently, a contract with incurrence provisions) requires the firm to comply with its financial covenants only in the event that a firm pursues (incurs) an active event, such as issuance of additional financing, sale of assets, or merger. In contrast, a "cov-heavy" contract (a contract with maintenance provisions) requires the issuer to maintain its compliance with contractual financial covenants at all points in time. ${ }^{1}$ For example, a prominent financial covenant in many loans is the leverage ratio, which limits firm indebtedness to a multiple of earnings before interest, taxes, depreciation, and amortization (EBITDA). A drop in a firm's EBITDA due to operational deterioration typically leads to a violation of a cov-heavy, but not a cov-lite, loan contract.

Cov-lite loans existed as a fringe phenomenon in corporate lending for several years, but took off in the years prior to the financial crisis. The financial crisis saw their issuance drop again. As indicated in Figure 1, although covenant-light issuance disappeared in 2008, it then reemerged in 2009. By the end of 2012, quarterly covenant-light origination had surpassed its earlier peak ( $25 \%$ of loan issuance as of 2007:Q2) and it remained substantially above that level through the

\footnotetext{
${ }^{1}$ Effectively, maintenance covenants are tested for compliance every fiscal quarter.
} 
end of 2014. In the first quarter of $2014,43 \%$ of all new leveraged loans and $54 \%$ of the volume of leveraged loan dollar flows were cov-lite. ${ }^{2}$

\section{[FIGURE 1]}

It has been argued that high recent issuance of cov-lite loans reflects reaching-for-yield - a preference for assets with partially-priced, but generally hard-to-measure, risk-spurred by the prolonged low interest rate environment. Stein (2013) points out that investors that are reaching for yield may be willing to forego control rights in order to boost yields, even if those control rights are more valuable, because yields are visible to investors and included in performance benchmarks, whereas control rights are less visible and are not explicitly accounted for in benchmarks. This observation is consistent with the fact that, as the incidence of cov-liteness in loans was rising, the spreads for leveraged loans did not compress - they remained substantially above historic levels, even excluding the securitization boom.

In this paper we argue that the rise in cov-lite issuance, to a large degree, has to do with the ways contracts shift in response to changes in the investor base for leveraged loans. Historically, loans were almost always covenant-heavy. ${ }^{3}$ It is against this background that the rise in covliteness is typically seen as alarming. But this is not the right benchmark. Cov-liteness is exclusively a feature of leveraged loans, a segment of the loan market that is widely syndicated to a diverse group of institutional investors. In this loan segment, traditional lenders like banks and finance companies account for about $10-15 \%$ of loan origination (and arguably even less, as

\footnotetext{
${ }^{2}$ We follow industry jargon and refer to syndicated loans of low credit quality as "leveraged loans." This term is always used to refer to high risk loans, but the specific definition-i.e., the exact cut-off for the loan spread and overall leverage - might vary by source and time period. In our study we rely on Standard and Poor's classification.

${ }^{3}$ We should clarify that a detailed covenant structure is a feature of the so-called "cash-flow based loan," that is, senior secured debt that is not backed by easily tracked or valued collateral. In contrast, "asset backed" loans are typically backed by collateral like real estate, heavy machinery, airplanes, and credit card receivables.
} 
some of their stake is sold in the secondary market). The bulk of leveraged loans are funded by collateralized loan obligations (CLOs), loan mutual funds, hedge funds, and securities firms, and to a lesser degree, insurance companies and pension funds. Thus, the investor base for leveraged loans today looks much more like the investor base for high-yield bonds. Perhaps it is not that all alarming, then, that the contract between creditors and the borrower in this setting would be covlite, as it always has been for bonds.

The central point is that the use of covenants requires coordination among investors. Covenant violations constitute default, and accelerate all payments. Simply put, upon covenant violation, the loan becomes due immediately, which typically forces the borrower to file for bankruptcy protection. In practice, it is often better for both parties to renegotiate to avoid default. Indeed, Roberts and Sufi (2009) show that anticipated covenant violations often lead to renegotiations between borrowers and lenders. Thus, many financial covenants are intended to serve as triggers to renegotiation: covenant violations shift control toward creditors, but do not necessarily lead to bankruptcy. For credit provided by a single lender, such as a conventional bank loan, this negotiation takes place between two parties, the borrower and the lender. But for credit provided by many investors, renegotiation requires that multiple parties coordinate.

The presence of coordination costs between different investors suggests that the usefulness of covenants may depend on the size and composition of the group of investors. For example, the quantity of investors may matter: Gertner and Scharfstein (1991) argue that a major impediment to efficient reorganizations is the inability for dispersed creditors to coordinate bargaining among themselves and with the managers of the bankrupt firm. Likewise, Bolton and Scharfstein (1996) argue that capital structures with many creditors can deter efficient ex-post renegotiation of defaulted contracts. Taken together, these arguments would suggest that covenant-driven shifts in control from owners to creditors make less sense for firms that have a dispersed creditor base. For 
example, changing non-payment features of a bond's indenture typically requires an approval of at least two thirds (by value of bonds) of bondholders. As such, these changes involve a large number of investors, many of whom hold a large number of bonds without having detailed insights into individual issuers. ${ }^{4}$ Holding the number of investors fixed, coordination may also be more costly when investors have different preferences (e.g., Van den Steen, 2010).

We conjecture that creditor coordination costs-reflecting the number of investors, their identity, and the overall composition — are relevant for the design of leveraged loan contracts. Importantly, over time, institutional investors' demand for leveraged loans has been subject to substantial level and compositional shifts. This, in turn, affected coordination costs and optimal contract construction. Specifically, in periods when the investor base of a leveraged loan resembles that of a public bond (such as the last few years), loan contract covenants intended to lead to renegotiation become less attractive, and one should expect more bond-like (cov-lite) contracts, as well as a lower cost of such features. ${ }^{5}$

Apart from investor-driven explanations, the rise in cov-lite volumes could also be a borrower demand phenomenon. In the recent period, the popularity of cov-lite loan contracts might have increased among firms based on their experiences in the financial crisis. This is a prominent view among defenders of the recent increase in cov-lite issuance. ${ }^{6}$ From this perspective, given what

${ }^{4}$ As an example, in December 2014, Fidelity's Total Bond Fund, which invests across U.S. bond markets, held 2,453 different bonds, had a total assets of $\$ 16.9$ billion, and was run by a team of four. Fidelity's High Income Fund, which focuses on lower rated corporate bonds, had assets of \$5.7 billion and 594 holdings, and was run by a single manager.

${ }^{5}$ Conceptually, what we mean by "the price" of a contract feature (such as cov-lite) is the difference in promised yield to maturity between contracts with and without this feature. Measuring this price is challenging in practice. We discuss measurement issues in detail below.

6 'These 'ratio maintenance' covenants can often present future onerous restrictions to borrowing companies on managing their business, and in some cases ensuring the survival of their business. As a CFO, I don't want to be overly controlled by strict maintenance covenants that limit my ability to manage my company at exactly the time I need flexibility." From an op-ed by Steve Trollope, Chief Financial 
was learned from the crisis, more issuers may have then been willing to pay a higher yield to get cov-lite features. Indeed, it is worth keeping in mind that, although the leveraged loan market is quite sizable, it is relatively young and its contractual practices (as well understandings of the implications of these practices) are constantly evolving. Additionally, Billett, Elkhami, Popov, and Pungaliya (2015) propose an alternative interpretation of the time trend in cov-lite. In their model, the mix of banks and institutions (such as mutual funds and CLOs) investing in loans can drive the frequency of covenant light, just as under the coordination cost hypothesis we propose. Billett et al. assume that banks care more about borrowers' long-term performance (because of relationship rents), and are better at enforcing covenants. The main implication of the model is that covenant light loans are held by institutions. One difference between the predictions made by the Billett et al. model and the coordination cost hypothesis is the importance of the number of institutions in a renegotiation situation (such as one triggered by covenant violation). In the Billett et al. model, the number of institutions is not important, because different institutions of a given type agree costlessly. In coordination cost models, reaching agreement is generally increasingly harder the more parties are involved, so that the number of investors matters, as well as their type. We address this difference empirically below.

We start our empirical analysis by addressing the hypothesis that firm demand for cov-lite terms has increased since the financial crisis. Using an extensive sample of syndicated loans, we construct a covenant-light premium. We do so, first, by comparing the loan yields on new loans that are cov-lite and cov-heavy, controlling for several observable loan and issuer features. Second, we compare yields that the same borrower receives when refinancing a loan from covheavy to cov-lite, as compared to borrowers that also refinance their loans but continue with a

Officer for CoGen Power Solutions, LLC. "Leveraged Loans Should Be Lauded, Not Maligned," Forbes, September 26, 2014. 
cov-heavy contract. We show that, while cov-lite volumes have expanded, cov-lite pricing has contracted. If the time pattern of cov-lite were driven by borrowers alone, the implicit price of cov-lite would be expected to rise along with loan volumes. Thus, our finding contradicts the view that this phenomenon is driven by borrowers.

The bulk of our results focus on the hypothesis that the rise in cov-liteness is a response to the rise in coordination costs. Indeed, there are two episodes of considerable cov-lite issuance, one in 2006-2007 and one, even larger, in the period since 2010. These peaks in cov-lite issuance coincide with peaks in institutional shares of syndicated loans. We explore the time-series determinants of aggregate covenant-light frequency and pricing in more detail. In particular, we relate cov-lite volumes and prices to determinants of investor compositions: the net flow to CLOs that invest in leveraged loans, and to mutual funds (closed end, open end, and ETFs). We also relate volumes and prices to proxies for overheating in the credit markets: time-on-the-market, or how long it takes to syndicate and close on a new loan, and the break price as compared to starting price used by Ivashina and Sun (2011), as well as four variables measuring general credit market conditions from Gilchrist and Zakrajšek (2012) and Greenwood and Hanson (2013). If cov-lite provisions reflect irrational or exuberant behavior by investors, we expect these variables to be related to cov-lite features. If the coordination argument is correct, controlling for market level conditions, we expect higher flows into these investor categories to be reflected in more frequent cov-lite features for new issues.

The fund flow variables are associated with high cov-lite frequency and low pricing. In other words, the time series is consistent with the coordination theory. The $R$-squared in the time series is high (above 0.50 for volumes, and above 0.10 for cov-lite premiums, which contain more noise). The overheating variables have some correlation with volumes and prices of cov-lite, but this correlation is inconsistent and often insignificant. The credit condition variables are also 
weakly related to both the price and volume of cov-lite. Thus, time series patterns lend most support to the coordination theory of cov-lite. These results are robust to the inclusion of macroeconomic forecasts.

The second set of results that directly backs the coordination hypothesis examines the crosssectional determinants of covenant-light contracts. That is, holding the point in time fixed, we investigate which loans are cov-lite and which are not. To do so, we collect data on CLOs' and mutual funds' loan-level holdings. As predicted, the loans that have many CLO or mutual fund investors are considerably more likely to be covenant-light. ${ }^{7}$ Extending the analysis to maturity and amortization, which also influence when and how creditors have control, we find that the same ownership structures that are associated with cov-lite also have long maturities and less amortization. A 5\% increase in the ownership stake of mutual funds and CLOs is associated with a 3.2\% increase in the likelihood of cov-lite structures (about half of the unconditional average); a $2.0 \%$ drop in the likelihood that the loan amortizes before maturity (about half of the unconditional average); and a 0.2 -year increase in loan maturity (the mean maturity is around 4.5 years). These results hold for CLOs and mutual funds individually, and as such are unlikely to be driven by individual institutional features. Moreover, building on stock mutual funds literature, we show that a mutual fund manager's inattention to an individual loan, as proxied by the number of holdings in their portfolio, is strongly positively correlated with their propensity to hold covlite loans.

7 There should be no causal interpretation here in the context of individual loans. There is matching between covenant-light loans and passive, dispersed investors. The design of an individual loan contract happens before the actual investor composition is determined. However, this contract design likely depends on both issuer preferences and market conditions, the latter perhaps transmitted to the firm by the lead bank or other financial advisors. 
Apart from the number and dispersion of creditors, we also examine the role of disagreement. For loans where CLOs and mutual funds have similar shares-wherein disagreement between them might matter to ex-post renegotiation outcomes - the likelihood of cov-lite terms is especially high. The two effects appear separate: both the dispersion of investors and the risk of ex-post disagreement due to different preferences appear linked to cov-lite terms. We conclude that the association between passive institutions and weak control rights is prominent in the cross-section of leveraged loans as well as in the aggregate time series.

Our results do not reject irrational pricing or overheating in corporate credit markets in the sense of Stein (2013), but do offer support for a different mechanism: the proximate cause of the rise of cov-lite loan features appears largely to be the composition of investors. Of course, the ultimate cause of this flow may itself be more or less rational and benign (for example, see Kacperczyk and Schnabl, 2013, and Zhao, 2005). Our results are silent on the efficiency of funding a very high share of loans from investors who might be passive in their assessment of the issuer's fundamentals. We leave this important question for other research.

\section{Data}

We use two main sources to collect data on corporate loan features: S\&P Leveraged Commentary and Data (LCD) and DealScan. DealScan is a widely used database of syndicated loan origination. LCD focuses on the leveraged segment of the syndicated loan market. As mentioned earlier, the cov-lite phenomenon is exclusive to the leveraged segment of the syndicated loan market, which makes LCD data particularly suitable for this study. We use LCD Pipeline, which tracks leveraged loans available for syndication, and also allows us to track loans that were ultimately closed. Importantly, LCD tracks cov-lite loans and reports them as part of its 
quarterly industry reviews. DealScan also has an indicator for cov-lite loans; however, reporting quality is poor. We classify loans as cov-lite based on indicators in LCD. ${ }^{8}$

Data capital flow into CLOs and loan mutual funds also comes from LCD. For the crosssectional results, we collect data on loan ownership by CLOs and mutual funds. CLO holding data is from trustee reports collected by CreditFlux and mutual fund holding data is from Morningstar.

We collect macro-economic forecasts from the survey of professional forecasters run by the Philadelphia Federal Reserve. In particular, we use the median four-quarter real GDP growth forecast. We also use time series variables measuring credit market conditions from Gilchrist and Zakrajšek (2012) and Greenwood and Hanson (2013). The variables are summarized in Table 1.

[TABLE 1]

\section{Cov-lite pricing}

We start by evaluating the proposition that the 2007-2008 financial crisis may have raised managers' willingness to pay for financial contract features that make them less vulnerable to financial turmoil and to loss of control to creditors. If increased cov-lite issuance reflected a shift in borrower demand for cov-lite loans (as more firms decide to pursue this option) — with an inelastic supply_-we would expect that the spread on cov-lite loans would have gone up. But the trend in prices was just the opposite: as illustrated in Figure 2, the drop in loan spreads in the post-crisis period was more pronounced for cov-lite loans than for cov-heavy loans. For cov-lite

${ }^{8}$ The classification is based on whether enforcement of financial covenants is incurrence-based, as for corporate bonds, or maintenance-based, as for traditional loans. While the distinction between maintenance and incurrence covenants (and hence that between cov-lite and cov-heavy leveraged loans) is essentially binary, a few intermediate cases also exist. For example, different categories of lenders may have different covenant protections, or covenants may become incurrence-based only when a certain amount of a revolving credit facility is drawn (these are called "springing covenants" or "quasi cov-lite" loans). These situations are sufficiently rare that we have not attempted to deal with them. 
loans, the spread drop between the first and second half of this period was roughly $170 \mathrm{bps}$ (from 615 bps to $445 \mathrm{bps}$ ), whereas for cov-heavy loans the drop over the same period was about $35 \mathrm{bps}$ (from 468 bps to 436 bps). ${ }^{9}$ A 135 -basis-point differential translated to a nearly a quarter drop in spreads for cov-lite loans.

The pooled averages in Figure 2 may be confounded by selection effects. In Figure 3, we present results after controlling for firm and loan characteristics such as deal size and purpose and issuer credit rating, all of which are allowed to vary with issuance quarter. As before, these results suggest that the price of covenant-light has been contracting, not increasing, contrary to the managerial preference view. The initial differential is smaller once one accounts for quality, but it still points to about a 50-basis-point drop in the price of cov-lite loans.

\section{[FIGURES $2 \& 3]$}

We should also consider shifts in the composition of the demand for cov-lite loans as an explanation for the pricing patterns in Figures 2 and 3. In particular, cov-lite provisions are often associated with higher quality issuers. (Indeed, large leveraged buyouts are most often not covlite, which is not to say that they do not have other contractual weaknesses.) This observation is consistent with a relatively small difference in the level of pricing between cov-lite and covheavy loans leading up to the financial crisis, or over the more recent period (note that the quality difference must be conditional on the control variables in Figure 3). Over time, this price difference has narrowed, which could reflect a rising average quality—an increasing fraction of better companies - choosing cov-lite provisions. One way to control for this quality difference is to look at loan refinancing. This would generally help to account for unobserved variation

9 According to the NBER, 2009:Q2 marks the end of the 2007-2009 economic recession. However, issuance of cov-lite loans over the later part of the recession period was nearly nonexistent. 2009:Q4 represents the first calendar quarter with at least two borrowers receiving cov-lite loans. 
remaining between firms of the same size and rating issuing loans of similar characteristics (but different covenant liteness).

In Figure 4 we examine loan pricing at refinancing. The refinancing decision is often dictated by the maturity of the outstanding loan, and in that sense is not influenced by market conditions (Almeida et al., 2012). The same point emerges from this analysis as from the cross-sectional comparison: while there is an overall drop in prices following the Great Recession, the drop in the prices of cov-lite loans is particularly aggressive. In the five-and-a-half years following the Great Recession, the spread for firms refinancing into cov-lite loans dropped from a roughly 70 bps premium in the first half of the period to zero in the second half of the period.

\section{[FIGURE 4]}

The rise in cov-lite issuance has been accompanied by a contraction in its pricing (i.e., the spread difference between otherwise comparable loans that are cov-lite and cov-heavy). This contradicts the view that this phenomenon is driven by borrowers (if the time pattern of cov-lite was driven by borrowers alone, the implicit price of cov-lite would be expected to rise as volumes rose). We next turn to whether fluctuations in the leveraged loan investor base, which are tied to the cost of coordination, can partially account for the increased incidence of covliteness.

\section{Coordination cost and incidence of cov-lite provisions}

Although leveraged loans are originated by banks, non-banks or institutional investors constitute the primary lender base in this market segment. According to S\&P, in 2014, at loan origination, only $10.4 \%$ of leveraged loans were held by banks. ${ }^{10}$ The three main institutional

\footnotetext{
${ }^{10}$ Due to the over-the-counter nature of the loan market, there is little information about participants in the secondary market. But arguably, the institutional base should only broaden through trading; in that sense,
} 
types dominating this market are collateralized loan obligations (CLOs), mutual funds, and hedge funds. In 2013, their total holdings exceeded $80 \%$ of loans at origination.

As illustrated in Figure 5, the institutional flow coincides with periods of cov-lite issuance. The correlation of the incidence of cov-lite with CLO issuance and with the flow into loan funds is 0.68 and 0.48 , respectively, both statistically significant at the $1 \%$ level. The number of different fund managers in this market —important from a coordination prospective- - follows a very similar pattern: it grew from 74 in 2000 to 307 (with nearly 900 different investment vehicles) in 2007. This includes managers who either participated in at least three loans or made at least $\$ 10$ million of commitments. After the securitization shutdown at the end of 2007 , the number of institutional groups investing in leveraged loans dropped almost by half. However, this number was essentially back to its pre-crisis level by the end of 2013, and reached 316 investor groups by mid-2014. ${ }^{11}$

\section{[FIGURE 5]}

While the number of investors engaging in the leveraged loan market in the post-crisis period is large, it is comparable to the pre-crisis levels; in contrast, the composition of the investor base following the crisis is more diverse and complex. In 2013, CLOs were still the largest institutional investor group, with roughly $45 \%$ of all primary holdings. But the new post-crisis phenomenon is a rise in loan mutual funds. The share held by these mutual funds nearly tripled following the financial crisis, rising from roughly $10 \%$ in 2006 to $27 \%$ by the end of 2013 . As we elaborate below, there are several structural differences between mutual funds and CLOs that might lead to differences in incentives during loan renegotiation, making coordination among

institutional investors' funding contribution in the primary market is a lower bound. Similarly, it is likely that the number of the investors increases once the loan starts trading and stakes acquired on the primary market get partially sold off.

${ }^{11}$ For more information on institutional engagement in the leveraged loan market see Ivashina (2013). 
creditors even more costly. Consequently, recent compositional changes in the leveraged loan investor base may have driven a rise in renegotiation costs.

\section{A. Time-series results}

We first consider correlates of the time series pattern of prices and volumes. We use the fraction (Table 2) and implied price on cov-lite (Table 3) as dependent variables. The implied price is a regression coefficient on a cov-lite indicator (separate for each calendar month or quarter) in a regression of loan yields on controls for size, size squared, maturity, loan rating, deal purpose, and loan type, all interacted with issuance quarter fixed effects (Figure 3 illustrates these prices). ${ }^{12}$

We explain the time series of volumes and prices at the monthly frequency (or quarterly, as robustness checks) in a regression with three groups of variables: capturing the loan investor composition, capturing general overheating, and capturing a generic time trend. As discussed above, the key leveraged loan investor categories are mutual funds and CLOs. We measure aggregate inflows, in billions of U.S. dollars, at the monthly frequency. When inflows are high, the coordination theory predicts higher volumes of cov-lite and lower prices. We measure overheating using two measures: the average time taken to close syndication on new loans, and the average price, as a fraction of par, at which new loans start trading in the secondary market (multiplied by 1,000). Both of these are expected to move if markets are somehow overheating in the sense of Stein (2013). They could also move for other reasons, so that significant coefficients need not be interpreted as firm evidence of mistakes or irrationality. We lag all the dependent

\footnotetext{
${ }^{12}$ The regression standard errors are adjusted for the fact that the dependent variable is estimated. A more efficient procedure estimating the coefficients of interest directly in one step is also possible, but the regression output is less easy to interpret.
} 
variables by one month to make sure we don't include market responses to issuance as dependent variables.

\section{[TABLES $2 \& 3]$}

In Table 2, we test whether coordination and overheating can explain the overall time pattern in volumes. Institutional investor flows are strongly related to volumes (positively), as well as prices (negatively). This holds whether or not we control for overheating variables, for variables measuring credit market conditions, and for a time trend. In Table 3, we test whether lagged variables can explain how implicit prices move over time. For both regressions, institutional flow is highly significant. Overheating variables have more mixed significance (four out of 12 coefficients at the monthly frequency are significant). The linear time trend is positively associated with volumes, but not pricing. The magnitude of the estimated effect of institutional flows on volumes is large: a one-standard-deviation increase in the institutional flow variables is associated with increases in the cov-lite share of $7.8 \%$ (CLOs) and $2.1 \%$ (mutual funds). The two variables explain about half of the time series variation in the cov-lite share. The effect on pricing is also large: one-standard-deviation increases reduce the price of cov-lite by $15 \mathrm{bps}$ and $13 \mathrm{bps}$, respectively. The $R$-squared is lower for prices, in line with the noisy nature of this time series.

\section{B. Cross-sectional results}

Table 4 shows results relating cov-lite to loan syndicate structures in cross-sectional micro data. The table uses a sample of 31,836 syndicated loans issued in the period from 2001-2014, and rated below investment grade at issue. We have data on loan features for a little more than 14,000 of these. In column (1), we document that there is a strong correlation between the number of mutual funds and CLOs participating in a loan syndicate at issue and the likelihood that the loan is cov-lite. Each mutual fund in the syndicate increases the likelihood of cov-lite by 
$1.9 \%$ and each CLO increases the likelihood by $2.1 \%$. In column (2), we control for the exact month when a loan was issued. The coefficient estimates in this column are therefore purely cross-sectional: if two loans are issued in the same month, is one with higher institutional ownership more likely to be cov-lite? The answer is yes, and magnitudes are virtually identical. In column (3), we add control variables. Large loans, long maturity loans, loans issued by private equity-controlled issuers, and loans used to fund LBOs are all more likely to be cov-lite. Furthermore, loans featuring no amortization ("Term Loan B" only loans) are more likely to be cov-lite. To the extent that repayment increases control rights, the lower rate of repayment and weak covenant protection may naturally go together. Controlling for these features, the number of institutional investors still strongly predicts cov-lite structure (with similar magnitude and significance).

Finally, we turn to sample splits. We divide the sample into large and small loans, using \$100 million as the cutoff. The effect of mutual fund ownership is larger and more significant for large loans, while the effect for CLOs is indistinguishable. Thus, there is no clear evidence of a different impact across loan sizes.

In Table 5, we repeat the same tests with amounts invested by passive institutions instead of the number of passive investors. We normalize the shares of mutual funds and CLOs, respectively, by loan size. Results are very similar to Table 4, in terms of both magnitudes and significance, except for sample splits. Here, the impact of the mutual fund share is much stronger for small loans (for the CLO share, the coefficient estimate is also largest for small loans, but the difference is not significant).

\section{[TABLES $4 \& 5]$}

Coordination can be costly because there are many parties involved, but also because the parties inherently disagree (as in the Billett et al. (2015) model). In column (6) of Table 5, we 
include both the dollar share of investors and number of institutional investors, to run a 'horse race' between the two types of variables. The number of investors appears more important, suggesting that coordination costs may be associated with having many passive investors. Another way to investigate the nature of coordination problems is to look at situations when CLOs and mutual funds may disagree. The interests of these two types of investors may differ in several ways. First, the managers at mutual funds and CLOs have different economics. In a mutual fund, investors hold a pro-rata claim on the collateral pool and the manager's incentives are tied to its performance. In a CLO, the claims over the collateral pool differ in their seniority. A CLO manager's incentives are typically tied up in the equity. So one fundamental conflict between a mutual fund manager and a CLO manager is akin to that between equity and debt (Jensen and Meckling, 1976). A CLO manager might prefer to risk-shift by delaying a loan restructuring, which is not the case for a mutual fund manager. In addition, differences in institutional features — such as marking to book for a CLO vs. marking to market for a mutual fund, or lack of redemptions for a CLO vs. mutual fund manager's sensitivity to redemptions, or a CLO hold-to-maturity structure with a limited ability to reinvest vs. active portfolio management for a mutual fund, or simply less powered incentives of a CLO manager vs. a mutual fund manager-could make the voting agents for CLOs and mutual funds behave differently. One prominent example of high coordination cost due to the misalignment of incentives is a loan amendment proposed by Momentive Performance Materials in $2009 .{ }^{13}$ The loan amendment was structured as a coercive exchange; this was a common practice for the bond market (where coordination is very costly, a necessary condition for a coercive exchange to go through), but until 2009 there was no precedent for this practice in the loan market. This case

\footnotetext{
${ }^{13}$ More details on this case can be found in Ivashina, V., and D. Scharfstein, "Momentive Performance Materials, Inc." Harvard Business School Case 210-081.
} 
specifically highlights the conflict between CLOs and hedge funds, pointing out that the proposal would not have been possible in that context. ${ }^{14}$

When there is potential for disagreement about how to handle future covenant violations, it might be optimal to have a lower risk of triggers, i.e., a cov-lite loan. Put differently, when investing in a covenant-light loan, mutual funds and CLOs may be able to disregard the potential for costly disagreement around renegotiation options, simply because renegotiations are unlikely. We assess this hypothesis by identifying deals where CLOs and mutual funds are likely to have similar influence. We use an indicator variable equal to one when, at loan issue, the proportion of the aggregate share held by CLOs to the aggregate share held by mutual funds is between $1 / 3$ and 3 (i.e., neither group has more than three times the share of the other group), and the total share of CLOs and mutual funds exceeds $5 \% .{ }^{15}$ Table 6 presents the results, including this indicator; controls in each specification are the same as those used in Table 5. In all specifications, the estimated coefficient on the indicator is around 0.25 . In other words, the combination of (nontrivial) investment by both types of institutions is associated with a 25-percentage-point higher likelihood of the loan being cov-lite. The coefficients on MF and CLO share remain significant and similar in magnitude to the results reported in Table 5. Although these results are based on a small number of loans that simultaneously have comparable CLO and mutual fund investment, they suggest that sharing power between two kinds of institutional investors with different preferences is unattractive, resulting in limited control rights as manifested in cov-lite terms.

$$
\text { [TABLE 6] }
$$

\footnotetext{
${ }^{14}$ At that point, mutual funds were not yet a prominent player in the leveraged loan market; however, a hedge fund manager's incentives are similar in many ways to a mutual fund manager's incentives.

${ }^{15}$ Results are not sensitive to changes in either the range of relative vote shares or the $10 \%$ total share.
} 
Cross-sectional results cannot be explained by a time-series phenomenon like reaching-foryield triggered by prolonged low-interest-rate environment pointed out by Stein (2013). But it is possible that, at a given point in time, institutional investors are inherently more attracted to loans with weaker control rights due to a higher yield, and not due to coordination issues. Building on the stock mutual fund literature, we look at the relation between mutual fund inattention to individual loans (a proxy for high coordination cost) and the propensity to hold a cov-lite loan.

Mutual funds that invest in stocks are understood to be passive both in the sense of not deviating from benchmark portfolios (e.g. Cremers and Petajisto, 2009 and Cremers, Ferreira, Matos, and Starks, 2015) and of not intervening in portfolio companies (Harford, Jenter, and Li, 2011). This is consistent with a general pattern whereby active investors tend to hold fewer assets, but devote more time to each. Kothari and Warner (2001) report that the average number of companies held in stock mutual funds is 114. Brunnermeier and Nagel (2004) report that hedge funds, which may be more active, hold on average around 80 stocks, whereas Kaplan and Strömberg (2004) report a sample average of 6.1 portfolio companies per VC fund, and Metrick and Yasuda (2010) document a range of 15-30 investments. In line with the large number of holdings, mutual funds appear more passive than other institutions. For example, mutual funds are much less involved in portfolio companies than other institutions such as pension funds (Gillan and Starks 2000). Within mutual funds, this lack of active involvement also appears related to the number of assets held. Indeed, Cremers and Petajisto (2009) find that mutual funds respond to fund inflows by becoming more similar to a stock market index.

Assuming that the relation between the lack of activeness and number of holdings is also true for loan mutual funds, we examine whether loan mutual funds that are large (in terms of assets under management or in terms of a large number of separate holdings) may be especially prone to investing in loans with limited control rights that require active involvement, including a 
preference for covenant-light loans. We test this by comparing the cov-lite share of individual mutual funds with the number of loans they hold. In Figure 7, we plot the quarter-fund observations of number of holdings and cov-lite share (in value terms). As is clear from this figure, there is a strong positive relationship between the log of the number of holdings and covlite share. $^{16}$

\section{[FIGURE $7 \&$ TABLE 7]}

We provide more detailed results in Table 7. For each mutual fund and holding period (i.e., quarter), we calculate the value-weighted share of cov-lite loans of the portfolio. This ranges from zero to $16.4 \%$, with a mean of $2.2 \%$. We regress the cov-lite share on fund size, measured as number of assets and number of holdings, with no fixed effects in column (1), with time fixed effects in column (2), with fund fixed effects in column (3), and with both types of fixed effects in column (4). In most specifications, there is a positive association between the number of assets and the cov-lite share of fund holdings, and when we control for mutual fund fixed effects, there is a positive association between assets under management and cov-lite share. In columns (5) and (6), we show that this holds for both open-end and closed-end mutual funds (the point estimate for the coefficient is slightly higher for closed-end funds (the difference is not statistically significant). We conclude from Table 7 and Figure 7 that there appears to be a robust positive relationship between mutual fund size and holding more cov-lite loans. This is consistent with the mutual fund literature's finding that large mutual funds are the most passive, and consistent with the idea that covenant-light is a control tool that passive investors find less appealing.

\section{Other loan features}

\footnotetext{
${ }^{16}$ The relationship also holds with time fixed effects, mutual fund fixed effects, and with both. The linear trend in Figure 6 has a t-statistic of 3.4 with time FE and clustering by fund. The effect also holds within closed end and within open end funds.
} 
In this last section of the paper we explore the relation between cov-liteness and other contractual features. First, if the high incidence and low price of cov-lite in the recent period reflects high coordination costs, other features of loans that impact the need for coordination should demonstrate related time patterns. Specifically, we consider maturity and amortization. As covenant enforcement, these are some of the fundamental contractual differences between bank debt and bonds (e.g., Fridson, 2015). One way to increase creditor control is to ensure that the initial debt must be partially or completely repaid (i.e., amortized or repaid), and thus refinanced or renegotiated (e.g., Barnea, Haugen, and Senbert, 1980; Leland and Toft, 1996; and He and Xiong, 2011).

In Table 8 we present results with an indicator for non-amortizing loan status and total loan maturity at issue (we adjust the set of controls to match the dependent variable). For both variables, there is a statistically significant association with the share of CLOs and mutual funds in ownership structure. ${ }^{17}$ The effect holds whether or not we control for other loan features, such as loan size and private equity (PE)-related issuers. The magnitudes are modest but interesting. In loans where the share is positive, the average CLO and mutual fund shares are around $14 \%$ and $16 \%$, respectively. Moving from zero to these typical values is associated with an increase in the likelihood of no amortization of $1.8 \%$ and $4.5 \%$, respectively, and an increase in loan maturity of 0.37 years and 0.12 years, respectively. Therefore, it appears these contract features reflect similar forces beyond covenant type.

\section{[TABLE 8]}

The second set of results looks at four main categories of covenants: (i) restrictions on indebtedness; (ii) restrictions on liens; (iii) restrictions on payments; and (iv) restrictions on asset

\footnotetext{
${ }^{17}$ These results are similar using the number of investors instead of their share in the loan amount.
} 
sales. These are the four categories that are common for almost all senior secured debt contracts. The information on these features is tracked by XTRACT Research, which is the source of our data, and which is commonly used by investors in the leveraged loan market to assess contract terms. XTRACT is a relatively new company, and, as such, they have best coverage for the most recent period. In the data that we have, each category is rated "weak," "average," or "strong." We count these as 0,1 , and 2 . For each loan, we then aggregate covenant strength by adding up the four numbers to get a covenant strength index ranging from zero to eight (we get very similar results by treating average and strong as the same category). The index is available for 355 of the loans in our sample, has an average of 3.24, a median of 4 , and a standard deviation of 1.30 . We relate this index both to covenant light and to the mutual fund and CLO syndicate shares in Table 9.

\section{[TABLE 9]}

The results in Table 9 suggest that covenant tightness is unrelated to both the cov-lite indicator and the share of mutual funds and CLOs in a loan syndicate. There is a negative relation between tightness and the buyout indicator, suggesting that loans financing buyouts tend to have less tight covenants. The absence of a link here suggests that loan institutions do not buy weaker control across the board.

\section{Final remarks}

Credit markets exhibit strong cyclical patterns, which are associated with large swings in output and investment. Evidence suggests that credit is low in recessions in part because banks are unwilling to lend, i.e. the supply of loans is moving (see, e.g., Becker and Ivashina, 2014, Ivashina and Scharfstein, 2010, and Jimenez, Ongena, Peydro, and Saurina, 2012). This suggests 
that lending is "too low" in bad times, in the sense that frictions (in banking) have negative effects on growth.

To what extent are credit markets also "too easy" in good times? There is a well-understood theoretical mechanism that describes feedback between asset prices and leverage (e.g., Kiyotaki and Moore, 1997, and Geanakopolos, 2009). Other mechanisms involving agency problems or behavioral mistakes are also possible (see Stein, 2013). Understanding the extent to which credit market swings reflect irrational exuberance is key for informed monetary policy formation, for regulation, and for market participants.

In this paper, we consider a feature of syndicated loans-covenant-lightness - which has recently been linked to exuberance and overheating. We provide a comprehensive framework for thinking about cross-sectional patterns as well as trends in cov-lite loan issuance. We highlight that analyses of cov-lite loans must account for (i) loan prices, and (ii) the composition of the lender base.

Apart from the overheating explanation, an alternative theory suggests that optimal contracts should give weaker control mechanisms to loan syndicates when participants are less informed (as in Billett et al., 2015) and more dispersed (due to coordination costs). The recent uptick in cov-lite lending does coincide with broadened participation in loan syndicates by mutual funds, hedge funds, structured products, and other non-bank investors. A third explanation for the recent boom argues that the uptick in volume reflects a shift in borrower preferences: in the wake of the financial crisis, managers have increased the value they place on financial flexibility (which can be improved by cov-lite borrowing).

Time series patterns of volumes do not offer clean separations between the overheating, managerial flexibility, and coordination views of cov-lite, simply because there are few periods and many variables changing at once. Therefore, we consider two pieces of additional evidence: 
prices and cross-sectional variation in the use of cov-lite features. We document that holding observables fixed, the price (i.e., yield difference) between cov-lite and cov-heavy has fallen at the same time that the share of cov-lite rose rapidly. Thus, the "supply" of cov-lite, i.e., the willingness of investors to accept it, appears to have increased considerably. This rules out the managerial flexibility explanation of the recent cov-lite boom. The contracting explanation is consistent with a sizeable increase in the share of leveraged loan tranches being acquired by structured products.

We complement the time series findings with cross-sectional results, comparing loans with different ownership structures issued at the same time. We find a strong association between diverse ownership (many CLOs and mutual funds investing in a loan) and the incidence of covlite.

In this paper, we have followed regulatory and industry interest in cov-lite provisions. However, as far as credit cycles go, cov-liteness is just one of the contractual features that may be associated with weaker creditor control rights, increases in the risk of new credit, and possible reaching-for-yield. There is a multitude of other provisions (increased use of second liens and pay-in-kind provisions, to name a few) that are likely to make loans riskier, but fit with a more hands-off investor base. Cov-lite provisions are particularly interesting because the recent increase in volumes has been so steep and because the contracts are so similar to existing contracts in the bond market. However, we also document that loan repayment characteristics follow a related pattern: repayment is slower and later in loans that involve many CLOs and mutual funds. Thus, we document a broad connection between loan investors and loan characteristics that affect creditor control rights.

Finally, our results shows that credit markets match contract terms to both creditor and investor characteristics. When ownership changes, contract terms change. The data speaks a little 
less clearly on whether overheating, over-optimism, or irrational exuberance can also play a role in corporate credit markets. Our evidence suggests that overheating plays a limited role, controlling for investor composition. Whether or not an increased share of institutions in credit markets is on balance good or bad, whether it increases or reduces systemic risk, and whether it may be a sign of possible overheating (for example, due to yield chasing by retail investors or by regulated entities), is not addressed by our results. 


\section{References}

Almeida, Heitor, Murillo Campello, Bruno Laranjeira and Scott Weisbenner, 2012, "Corporate Debt Maturity and the Real Effects of 2007 Credit Crisis," Critical Finance Review, 1(1), 3-58.

Barnea, Amir, Robert A. Haugen and Lemma W. Senbert, 1980, "A Rationale for Debt Maturity Structure and Call Provisions in the Agency Theoretic Framework," Journal of Finance, 35(5), 1223-1234.

Becker, Bo, and Victoria Ivashina, 2014, "Cyclicality of Credit Supply: Firm Level Evidence," Journal of Monetary Economics 62, 76-93.

Benmelech, Efraim, Jennifer Dlugosz, and Victoria Ivashina, 2012, "Securitization without adverse selection: The case of CLOs," Journal of Financial Economics, 106(1), 91-113.

Billet, Matthew, Redouane Elkamhi, Latchezar Popov, and Raunaq Pungaliya, 2014, "Bank Skin in the Game and Loan Contract Design: Evidence from Covenant-Lite Loans," Journal of Financial and Quantitative Analysis, forthcoming.

Bolton, Patrick, and David, Scharfstein, 1996, "Optimal Debt Structure and the Number of Creditors," Journal of Political Economy 104, 1-25.

Cremers, K. J. Martin, Miguel A. Ferreira, Pedro P. Matos and Laura T. Starks, 2015, "Indexing and Active Fund Management: International Evidence,” working paper.

Cremers, K. J. Martin, and Antti Petajisto, 2009, "How Active Is Your Fund Manager? A New Measure That Predicts Performance," Review of Financial Studies, 22(9), 3329-3365.

Fridson, Martin, (editor), 2015, High Yield, Future Tense: Cracking the Code of Speculative Debt. New York Society of Security Analysts.

Geanakopolos, John, 2009, “The Leverage Cycle”, NBER Macroeconomics Manual, 24, 1-65.

Gertner, Robert, and David Scharfstetin, 1991, "A Theory of Workouts and the Effects of Reorganization Law," Journal of Finance 46, 1189-1221.

Gilchrist, Simon, and Egon Zakrajšek, 2012, "Credit Spreads and Business Cycle Fluctuations," American Economic Review, 102(4), 1692-1720.

Gillan, Stuart L., and Laura T. Starks, 2000, "Corporate governance proposals and shareholder activism: the role of institutional investors," Journal of Financial Economics, 57, 275-305.

Greenwood, Robin, and Samuel G. Hanson, 2013, "Issuer Quality and Corporate Bond Returns," Review of Financial Studies, 26(6), 1483-1525.

Harford, Jarrad, Dirk Jenter and Kai Li, 2011, "Institutional cross-holdings and their effect on acquisition decisions," Journal of Financial Economics, 99, 27-39.

He, Zhiguo, and Wei Xiong, 2011, “Rollover Risk and Credit Risk,” Journal of Finance, 67(2), 391-430. 
Ivashina, Victoria, and David Scharfstein, 2010, "Bank Lending During the Financial Crisis of 2008," Journal of Financial Economics 97, 319v338.

Ivashina, Victoria, and Zheng Sun, 2011, "Institutional Demand Pressure and the Cost of Corporate Loans," Journal of Financial Economics 99, 500-522.

Jensen, M., and W. Meckling, 1976, "Theory of the Firm: Managerial Behavior, Agency Costs, and Capital Structure," Journal of Financial Economics 3, 305-360.

Jimenez, Gabriel, Steven Ongena, Jose-Luis Peydro and Jesus Saurina, 2012, "Credit Supply and Monetary Policy: Identifying the Bank Balance-Sheet Channel with Loan Applications," American Economic Review, 102(5), 2301-2326.

Kacperczyk, Marcin, and Philipp Schnabl, 2013, “How Safe are Money Market Funds," The Quarterly Journal of Economics, 128(3), 1073-1122.

Kiyotaki, Nobuhiro, and John Moore, 1997, “Credit Cycles,” Journal of Political Economy, 105(2), 211248.

Kothari, S. P., and Jerold P. Warner, 2001, "Evaluating Mutual Fund Performance," Journal of Finance, 61(5), 1985-2010.

Leland, Hayne, and Klaus Bjerre Toft, 1996, "Optimal capital structure, endogenous bankruptcy, and the term structure of credit spreads," Journal of Finance 51(3), 987-1019.

Metrick, Andrew, and Ayako Yasuda, 2010, "The Economics of Private Equity Funds," Review of Financial Studies, 23(6), 2303-2341.

Roberts, Michael, and Amir Sufi, 2009, "Renegotiation of Financial Contracts: Evidence from Private Credit Agreements," Journal of Financial Economics 93, 159-184.

Stein, Jeremy, 2013, Remarks at the Restoring Household Financial Stability after the Great Recession Research Symposium, Federal Reserve Bank of St. Louis,

www.federalreserve.gov/newsevents/speech/stein20130207a.htm.

Smith, Clifford, and Jerold Warner, 1979, "On Financial contracting: an Analysis of Bond Contracts," Journal of Financial Economics 7, 117-161.

Van den Steen, Eric , 2010, "Disagreement and the Allocation of Control," Journal of Law, Economics, \& Organization, 26(2), August, 385-426.

Zhao, Xinge, 2005, "Determinants of Flows into Retail Bond Funds," Financial Analysts Journal, 61(4), July, 47-59. 
FIGURE 1. COV-LITE LOAN ISSUANCE, 1997-2014

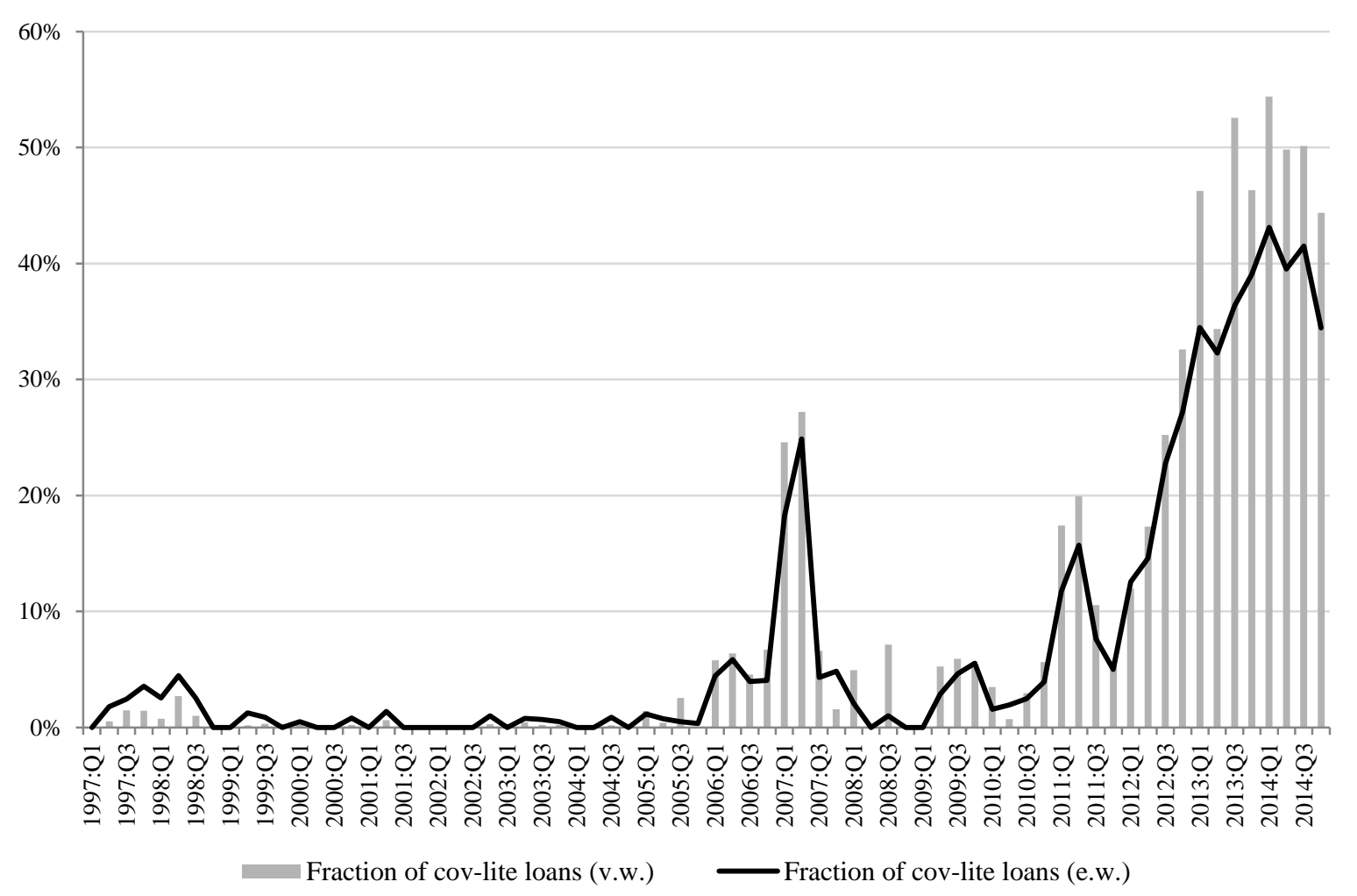

Notes: The figure plots the fraction of newly issued leveraged loans that are "covenant-light." Data is compiled from Standard and Poor's LCD U.S. loan pipeline data accessed on December 4, 2014. The sample excludes deals classified by S\&P as Middle Market. The volume for the fourth quarter of 2014 is estimated using data through November 30, 2014. 


\section{FIGURE 2. LOAN SPREAD: COV-LITE VS. COV-HEAVY LOANS}

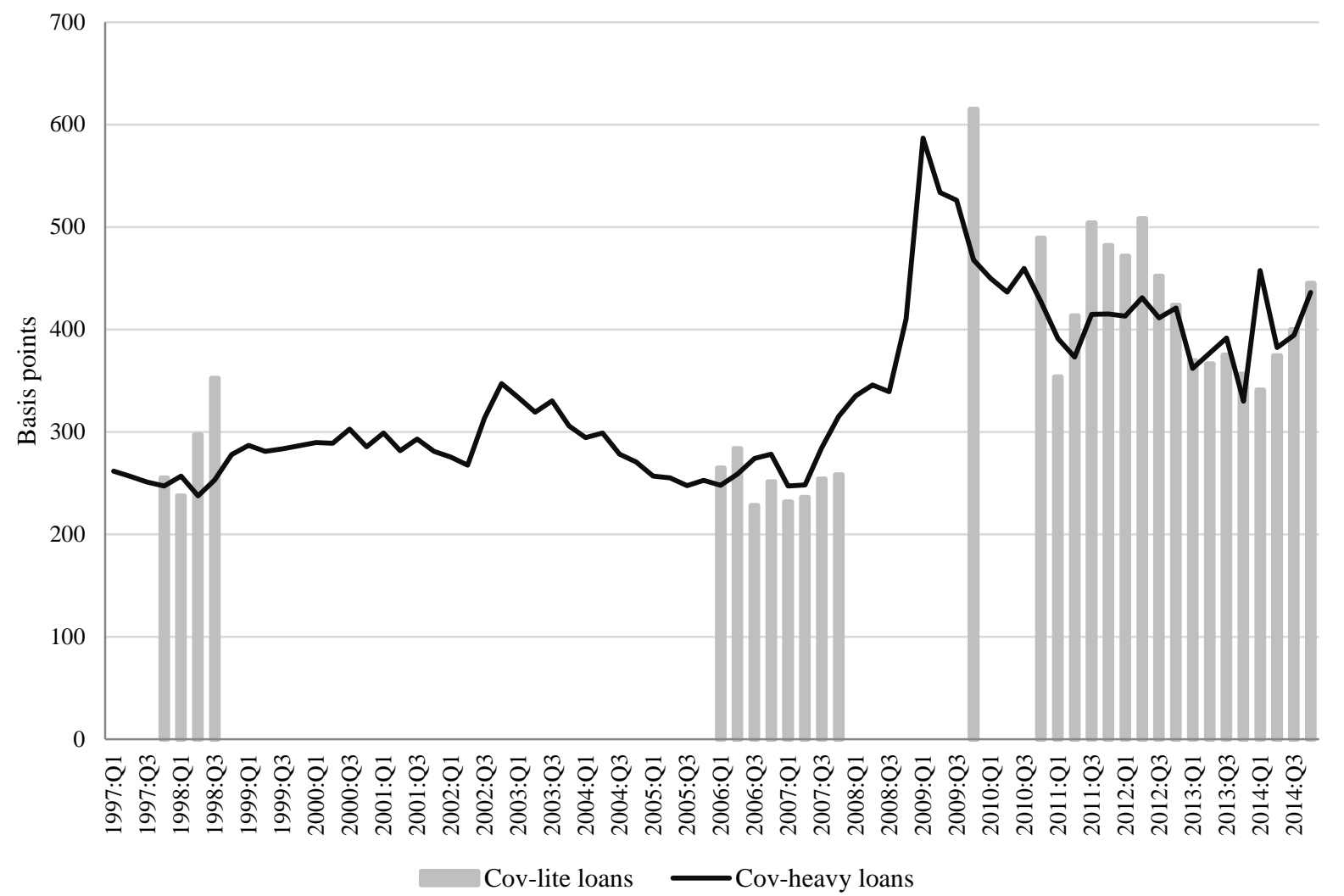

Notes: The figure plots all-fees-in-drawn spread paid over LIBOR. Data is compiled from Standard and Poor's LCD U.S. loan pipeline data accessed on December 4, 2014. The sample excludes deals classified by S\&P as Middle Market. For cov-lite loans, the sample excludes quarters with fewer than two borrowers receiving new loans. 


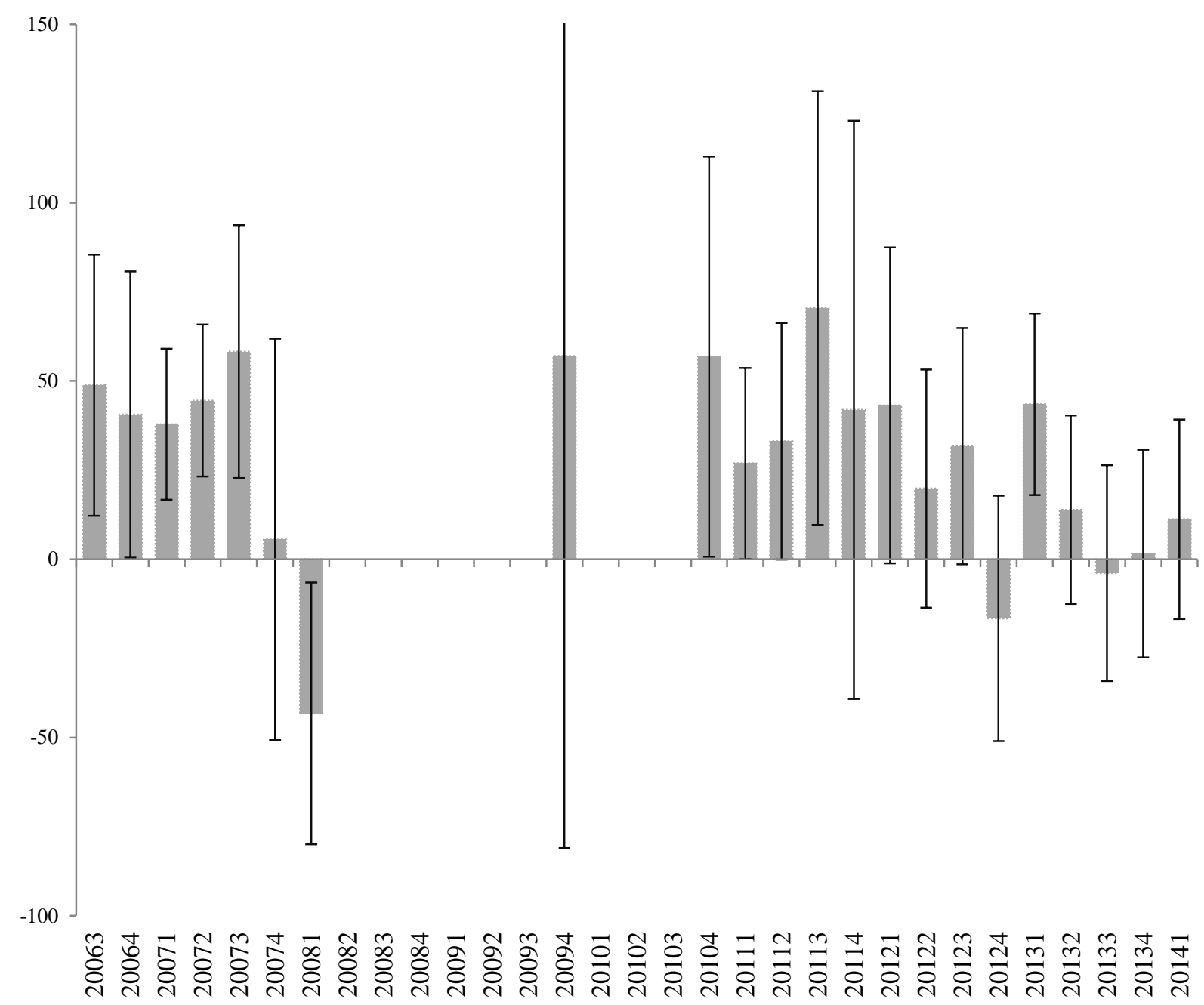

Notes: The figure plots all-fees-in-drawn spreads paid over LIBOR for cov-lite loans. Each column represents the coefficient on a covenant-light indicator, controlling for size, size squared, maturity, loan rating, deal purpose, loan type, all interacted with issuance quarter fixed effects. Data is compiled from Standard and Poor's LCD U.S. loan pipeline data accessed on December 4, 2014. The sample excludes deals classified by S\&P as Middle Market. Error bars indicate 95\% confidence intervals based on robust standard errors. 
FIGURE 4. COV-LITE PREMIUM: EVIDENCE FROM REFINANCING

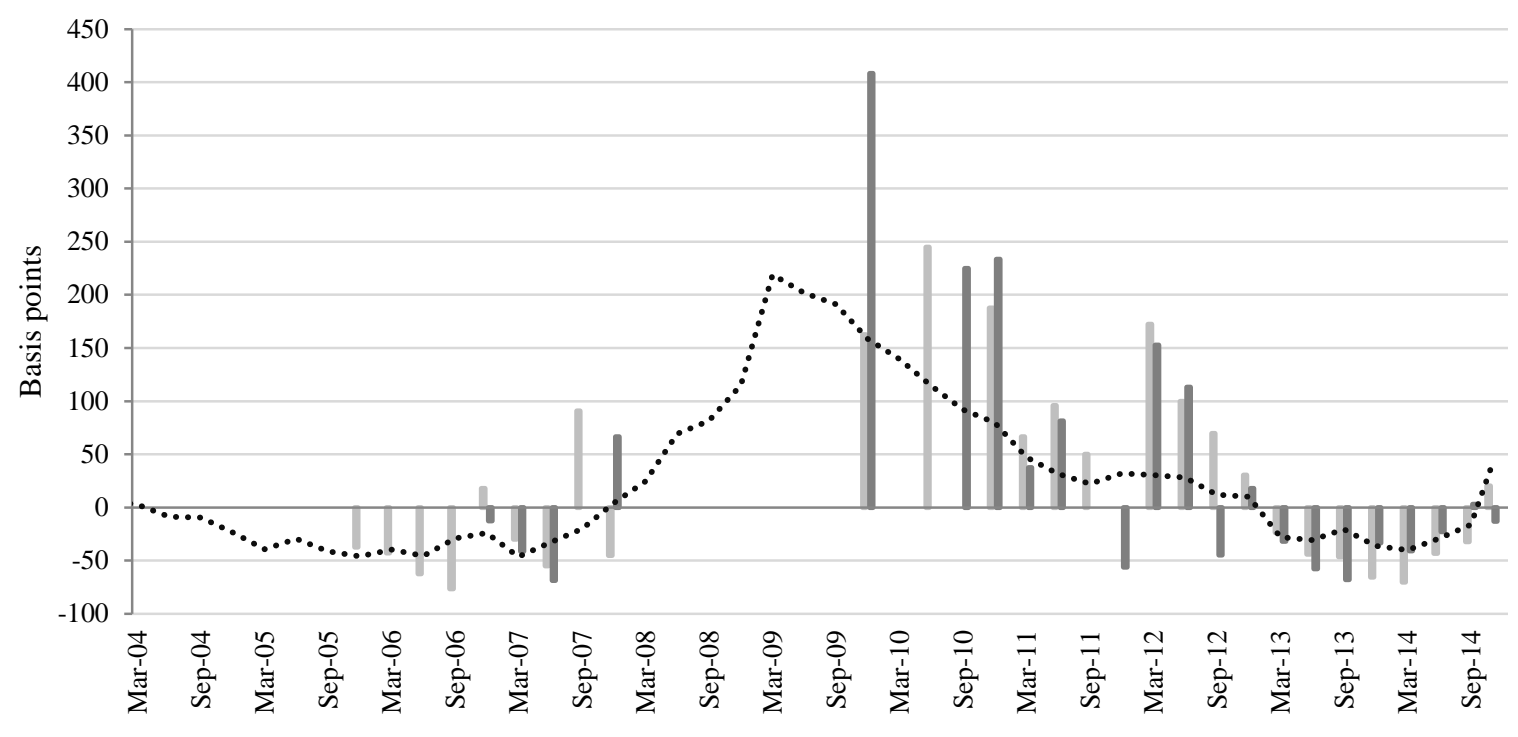

$\Delta$ Spread, from cov-heavy to cov-lite

$\Delta$ Spread, from cov-lite to cov-lite

…... $\Delta$ Spread, from cov-heavy to cov-heavy

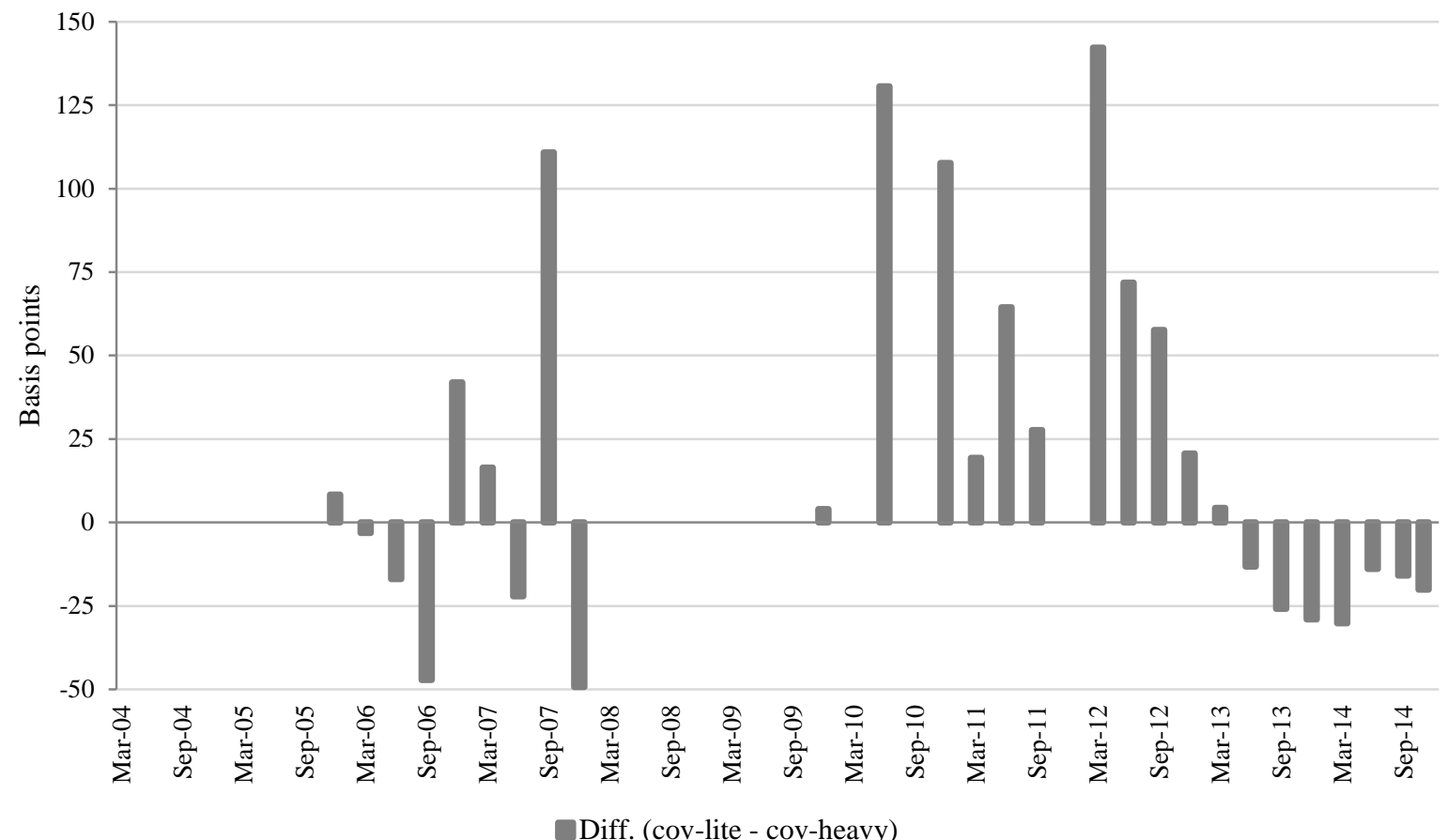

Notes: The figure plots change in all-fees-in-drawn spread paid over LIBOR by the same borrower paid on refinanced loans. Data is compiled from Standard and Poor's LCD U.S. loan pipeline data accessed on December 4, 2014 and DealScan. For cov-lite loans, the sample excludes quarters with fewer than two borrowers receiving new loans. 


\section{FIGURE 5. LOAN MARKET INSTITUTIONAL FUND FLOW}

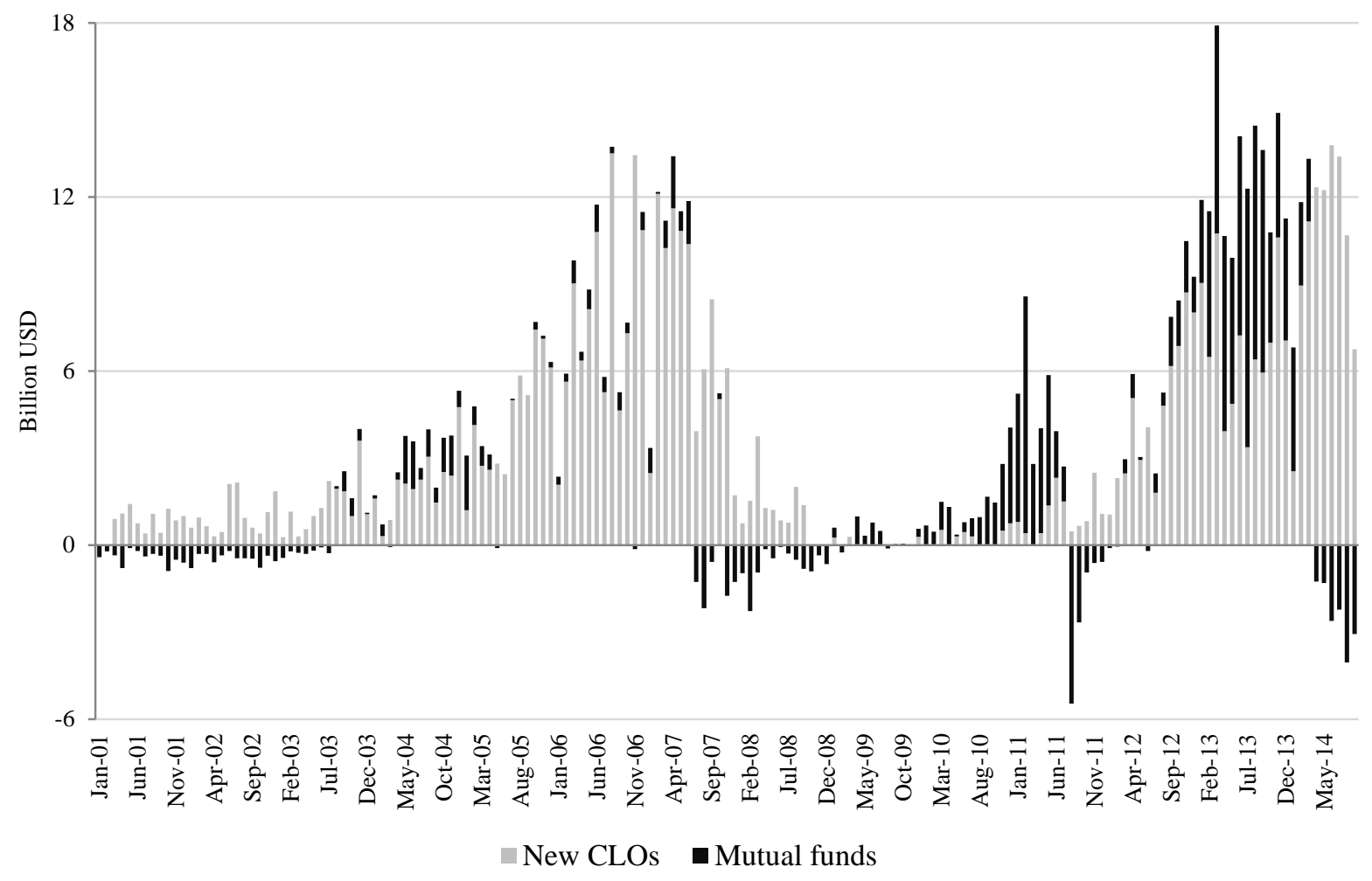

Notes: The figure plots fund flow into collateralized loan obligations (CLOs) and loan mutual funds. Both of the institutional types concentrate their assets in leverage loans. The figure uses data from Lipper downloaded from Standard and Poor's LCD. 
FIGURE 6. MICRO EVIDENCE ON COV-LITE LOAN OWNERSHIP
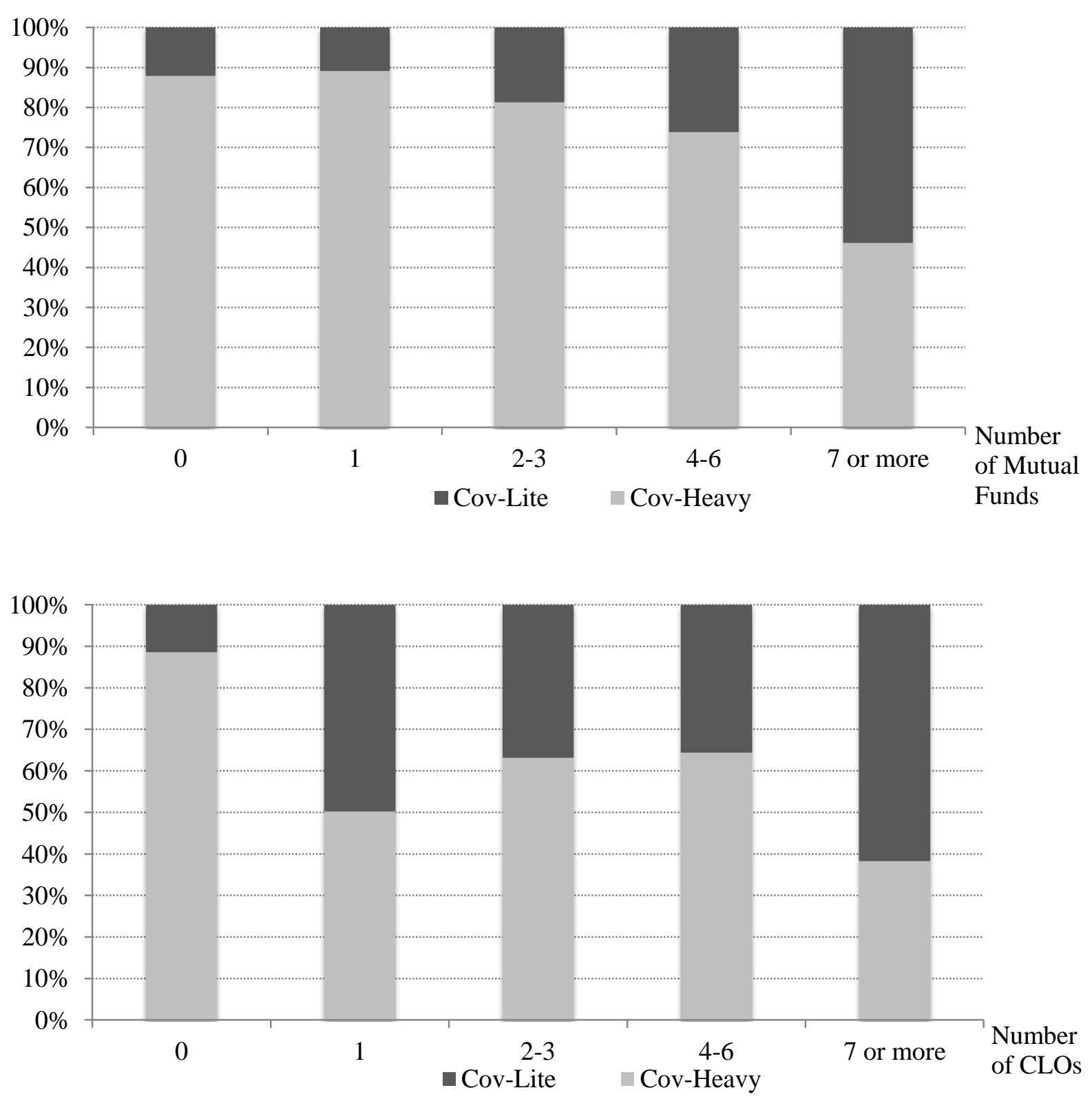

Notes: The figures plot the mix of cov-lite and cov-heavy loans by number of institutional owners participating in each loan at issue. Institutional owners are loan mutual funds in the first panel and collateralized loan obligations (CLOs) in the second. The figure uses data from Lipper downloaded from Standard and Poor's LCD. 


\section{FIGURE 7. MUTUAL FUND SIZE AND COV-LITE LOAN OWNERSHIP}

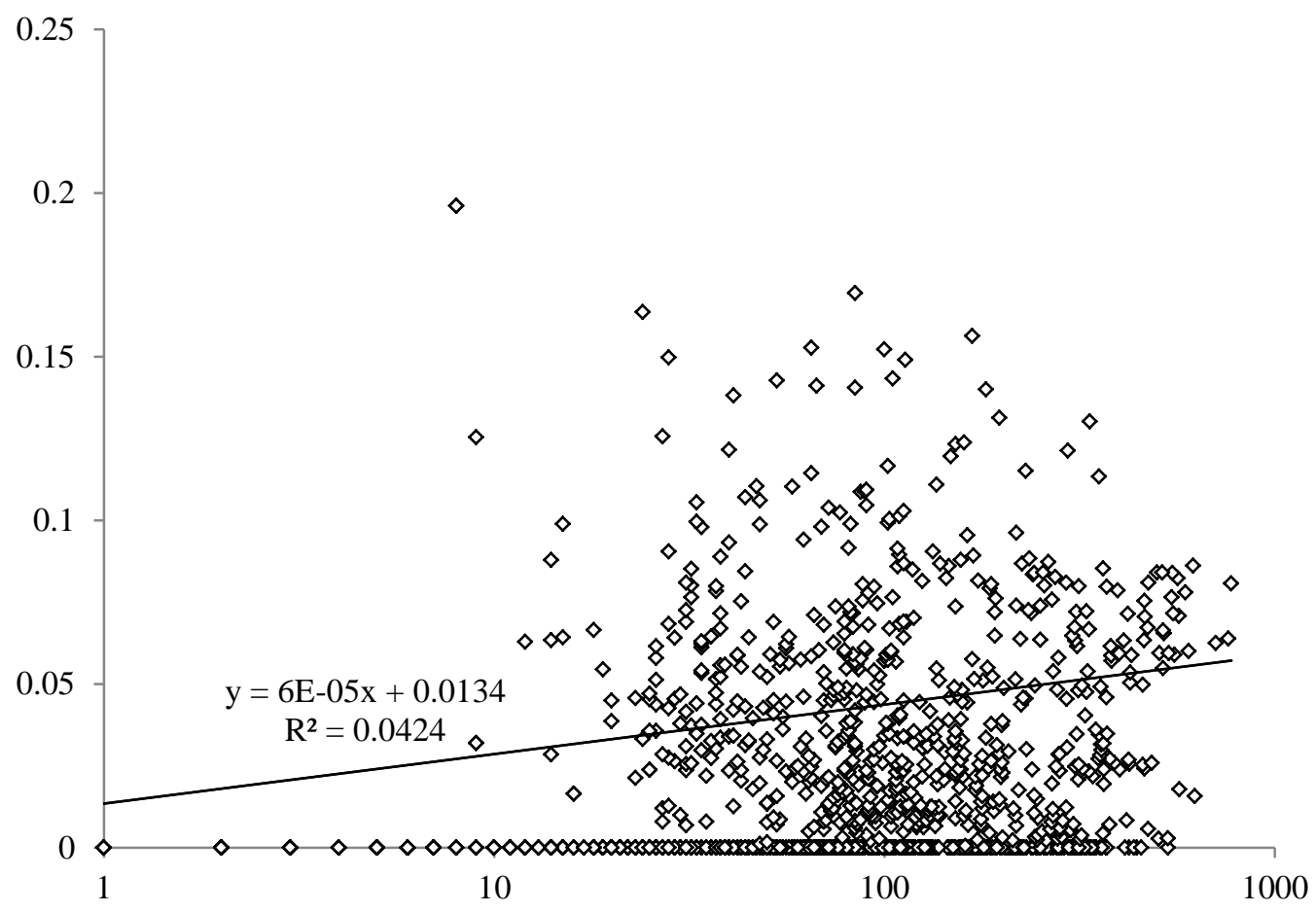

Notes: The figure plots value-weighted share of cov-lite loans for a mutual fund in a given quarter against the total number of loan holdings. 
TABLE 1. SUMMARY STATISTICS

\begin{tabular}{lrrrr}
\hline \hline Variable: & & & & \\
& Mean & $\begin{array}{r}\text { Standard } \\
\text { deviation }\end{array}$ & Minimum & Maximum \\
& & 4.27 & 0 & 13.78 \\
\hline Institutional inflow: CLOs (\$ billion) & 0.98 & 2.54 & -5.46 & 8.91 \\
Institutional inflow: Mutual funds (\$ billion) & 18.55 & 6.74 & 4.00 & 47.10 \\
Time on the market (days) & 991.6 & 22.4 & 815 & $1,012.9$ \\
Break price (relative to par x 1,000) & 2.83 & 1.43 & 1.43 & 7.95 \\
Bond spread (Gilchrist and Zakrajšek, 2012) & 0.334 & 0.119 & 0.053 & 0.504 \\
High yield share (Greenwood and Hanson, 2013) & 32.0 & 26.5 & -43.2 & 70.4 \\
Cov-lite price, quarterly estimate & -31.0 & 55.4 & -277.7 & 150.8 \\
Cov-lite price, monthly estimate & 14.1 & 14.3 & 0 & 43.1 \\
Cov-lite share, leveraged loans (\%) & 0.13 & 1.08 & 0 & 20 \\
Syndicate: Number of MFs & 0.17 & 1.57 & 0 & 20 \\
Syndicate: Number of CLOs & & & & \\
\hline
\end{tabular}

Notes: This table presents summary statistics for times series variables. Institutional inflow represents inflow minus outflow to key investors in leveraged loans, based on data from Lipper, Standard \& Poor's Structured Finance Group, JP Morgan, Merrill Lynch, Citigroup, S\&P/LSTA Index, Standard \& Poor's LCD. Mutual funds include open-end funds, close-end funds, and ETF funds. Time on the market is the average time between when a new loan is introduced and when the deal is closed. Break price is the price at which a loan first trades in the secondary market, as a fraction of par. Cov-lite price is a regression coefficient on a cov-lite indicator, controlling for size, size squared, maturity, loan rating, deal purpose, and loan type, all interacted with issuance quarter fixed effects (se Figure 3). When nothing else is indicated, a variable is measured at monthly frequency. 
TABLE 2 - TIME-SERIES CORRELATES OF COV-LITE VOLUMES

\begin{tabular}{|c|c|c|c|c|c|c|}
\hline \multirow{2}{*}{$\begin{array}{l}\text { Dependent variable: } \\
\text { Frequency: }\end{array}$} & \multicolumn{6}{|c|}{ Cov-lite share of leveraged loans } \\
\hline & $\begin{array}{l}\text { Monthly } \\
\text { (1) }\end{array}$ & $\begin{array}{l}\text { Monthly } \\
\text { (2) }\end{array}$ & $\begin{array}{l}\text { Monthly } \\
\text { (3) }\end{array}$ & $\begin{array}{l}\text { Monthly } \\
\text { (4) }\end{array}$ & $\begin{array}{l}\text { Monthly } \\
\text { (5) }\end{array}$ & $\begin{array}{l}\text { Monthly } \\
\text { (6) }\end{array}$ \\
\hline Institutional inflow: CLOs & $\begin{array}{l}1.960 * * * \\
(0.451)\end{array}$ & -- & $\begin{array}{l}2.160 * * * \\
(0.314)\end{array}$ & $\begin{array}{l}1.816^{* * * *} \\
(0.194)\end{array}$ & $\begin{array}{l}0.564^{*} \\
(0.311)\end{array}$ & $\begin{array}{l}1.251^{* * * *} \\
(0.281)\end{array}$ \\
\hline Institutional inflow: Mutual funds & $\begin{array}{l}1.913 * * * \\
(0.626)\end{array}$ & -- & $\begin{array}{l}1.582 * * * \\
(0.469)\end{array}$ & $\begin{array}{l}0.836 * * * \\
(0.266)\end{array}$ & $\begin{array}{l}1.549 * * \\
(0.607)\end{array}$ & $\begin{array}{l}0.735^{* * *} \\
(0.330)\end{array}$ \\
\hline Time on the market & -- & $\begin{array}{l}-0.724^{*} \\
(0.376)\end{array}$ & $\begin{array}{l}-0.828 * * \\
(0.340)\end{array}$ & $\begin{array}{l}0.074 \\
(0.252)\end{array}$ & -- & -- \\
\hline Break price & -- & $\begin{array}{l}0.124 \\
(0.102)\end{array}$ & $\begin{array}{l}-0.079 \\
(0.050)\end{array}$ & $\begin{array}{l}-0.011 \\
(0.026)\end{array}$ & -- & -- \\
\hline Bond spreads & -- & -- & -- & -- & $\begin{array}{l}-4.337 * * \\
(1.792)\end{array}$ & $\begin{array}{l}-2.063 \\
(1.278)\end{array}$ \\
\hline High yield share & -- & -- & -- & -- & $\begin{array}{l}8.618 \\
(8.532)\end{array}$ & $\begin{array}{l}4.404 \\
(6.070)\end{array}$ \\
\hline Real GDP forecast & -- & -- & -- & -- & $\begin{array}{l}-8.719^{*} \\
(4.714)\end{array}$ & $\begin{array}{l}-397.2 \\
(267.8)\end{array}$ \\
\hline Linear time trend & -- & -- & -- & $\begin{array}{l}3.606 * * * \\
(0.388)\end{array}$ & -- & $\begin{array}{l}2.268^{* * * *} \\
(0.378)\end{array}$ \\
\hline Observations & 104 & 104 & 99 & 99 & 85 & 85 \\
\hline Clusters & 35 & 36 & 35 & 35 & 29 & 29 \\
\hline$R$-squared & 0.504 & 0.194 & 0.630 & 0.849 & 0.459 & 0.679 \\
\hline
\end{tabular}

Notes: This table presents regression of the share of leveraged loans that are cov-lite on time series variables. The independent variables are CLO issuance and net inflows to mutual funds specializing in loans, the average time taken to close syndication on new loans, and the average price, as a fraction of par, at which new loans start trading in the secondary market (multiplied by 1,000). All independent variables are monthly, and are lagged by one month. Robust standard errors, clustered by calendar quarter, are reported below each coefficient in brackets.

*** Significant at the 1 percent level.

** Significant at the 5 percent level.

* Significant at the 10 percent level. 
TABLE 3 - TIME-SERIES CORRELATES OF COV-LITE PRICING

\begin{tabular}{|c|c|c|c|c|c|c|c|}
\hline \multirow{2}{*}{$\begin{array}{l}\text { Dependent variable: } \\
\text { Frequency: }\end{array}$} & \multicolumn{7}{|c|}{ Cov-lite price } \\
\hline & $\begin{array}{l}\text { Monthly } \\
\text { (1) }\end{array}$ & $\begin{array}{l}\text { Monthly } \\
\text { (2) }\end{array}$ & $\begin{array}{l}\text { Monthly } \\
\text { (3) }\end{array}$ & $\begin{array}{c}\text { Monthly } \\
\text { (4) }\end{array}$ & $\begin{array}{l}\text { Monthly } \\
\text { (5) }\end{array}$ & $\begin{array}{c}\text { Monthly } \\
\text { (6) }\end{array}$ & $\begin{array}{l}\text { Quarterly } \\
\text { (7) }\end{array}$ \\
\hline Institutional inflow: CLOs & $\begin{array}{l}-2.479^{*} \\
(1.379)\end{array}$ & -- & $\begin{array}{c}-3.501 * * * \\
(1.1175)\end{array}$ & $\begin{array}{c}-3.504 * * * \\
(1.195)\end{array}$ & $\begin{array}{c}-6.851^{* *} * \\
(3.129)\end{array}$ & $\begin{array}{c}-6.252 * \\
(3.580)\end{array}$ & $\begin{array}{c}-2.635 * * * \\
(0.782)\end{array}$ \\
\hline Institutional inflow: Mutual funds & $\begin{array}{l}-3.420^{*} \\
(1.572)\end{array}$ & -- & $\begin{array}{c}-5.167 * * * \\
(1.430)\end{array}$ & $\begin{array}{c}-5.175^{* * *} \\
(1.494)\end{array}$ & $\begin{array}{c}-5.600 * * \\
(2.751)\end{array}$ & $\begin{array}{c}-6.149 * * \\
(2.900)\end{array}$ & $\begin{array}{c}-3.350 * * * \\
(1.721)\end{array}$ \\
\hline Time on market & -- & $\begin{array}{l}-0.180 \\
(0.595)\end{array}$ & $\begin{array}{l}-0.476 \\
(0.631)\end{array}$ & $\begin{array}{l}-0.448 \\
(0.708)\end{array}$ & -- & -- & $\begin{array}{c}1.198 * * \\
(0.520)\end{array}$ \\
\hline Break price & -- & $\begin{array}{c}0.075 \\
(0.756)\end{array}$ & $\begin{array}{l}1.017 * * \\
(0.486)\end{array}$ & $\begin{array}{l}1.017 * * \\
(0.493)\end{array}$ & -- & -- & $\begin{array}{c}1.327 * * * \\
(0.235)\end{array}$ \\
\hline Bond spreads & -- & -- & -- & -- & $\begin{array}{l}-119.7 \\
(73.77)\end{array}$ & $\begin{array}{l}-55.018 \\
(35.065)\end{array}$ & -- \\
\hline High yield share & -- & -- & -- & -- & $\begin{array}{c}-57.071 \\
(38.712)\end{array}$ & $\begin{array}{l}-121.97 \\
(80.24)\end{array}$ & -- \\
\hline Real GDP forecast & -- & -- & -- & -- & $\begin{array}{l}-41.828 \\
(29.433)\end{array}$ & $\begin{array}{l}-31.956 \\
(40.643)\end{array}$ & -- \\
\hline Linear time trend & -- & -- & -- & $\begin{array}{c}0.086 \\
(2.465)\end{array}$ & -- & $\begin{array}{c}1.527 \\
(5.285)\end{array}$ & $\begin{array}{c}-0.823 \\
(1.640)\end{array}$ \\
\hline Obs. & 71 & 73 & 71 & 71 & 52 & 50 & 71 \\
\hline Clusters & 26 & 27 & 26 & 26 & 20 & 20 & 24 \\
\hline$R$-squared & 0.059 & 0.006 & 0.091 & 0.091 & 0.143 & 0.144 & 0.497 \\
\hline
\end{tabular}

Notes: This table presents regression of the implicit price of cov-lite by time period on time series variables. The implicit price is the coefficient on a cov-lite indicator (separate for each calendar month or quarter) in a regression of loan yields on controls for size, size squared, maturity, loan rating, deal purpose, and loan type, all interacted with issuance quarter fixed effects (presented in Figure 3). The independent variables are new CLOs and net inflows to mutual funds specializing in loans, the average time taken to close syndication on new loans, and the average price, as a fraction of par, at which new loans start trading in the secondary market (multiplied by 1,000). All independent variables are monthly, and are lagged by one month. Robust standard errors, clustered by calendar quarter, are reported below each coefficient in brackets.

*** Significant at the 1 percent level.

** Significant at the 5 percent level.

* Significant at the 10 percent level. 
TABLE 4 - CROSS-SECTIONAL RESULTS (NUMBER OF INVESTORS AT ISSUE)

\begin{tabular}{|c|c|c|c|c|c|}
\hline \multirow{2}{*}{ Dependent variable: } & \multicolumn{5}{|c|}{ Incidence of cov-lite provisions } \\
\hline & $(1)$ & (2) & (3) & (4) & (5) \\
\hline Sample: & & & & $\begin{array}{l}\text { Below } \\
\$ 100 \mathrm{~m}\end{array}$ & $\begin{array}{l}\$ 100 \mathrm{~m} \text { or } \\
\text { larger }\end{array}$ \\
\hline Syndicate: Number of MFs & $\begin{array}{l}0.019 \text { *** } \\
(0.005)\end{array}$ & $\begin{array}{l}0.020 * * * \\
(0.005)\end{array}$ & $\begin{array}{l}0.017 * * * \\
(0.005)\end{array}$ & $\begin{array}{l}0.045 * * * \\
(0.010)\end{array}$ & $\begin{array}{l}0.012 * * \\
(0.005)\end{array}$ \\
\hline Syndicate: Number of CLOs & $\begin{array}{l}0.021 * * * \\
(0.004)\end{array}$ & $\begin{array}{l}0.017 * * * \\
(0.004)\end{array}$ & $\begin{array}{l}0.015 * * * \\
(0.004)\end{array}$ & $\begin{array}{l}0.015 * * * \\
(0.006)\end{array}$ & $\begin{array}{l}0.012 * * * \\
(0.004)\end{array}$ \\
\hline Loan size (million USD) & -- & -- & $\begin{array}{l}0.007 * * * \\
(0.001)\end{array}$ & $\begin{array}{l}0.002 * * * \\
(0.000)\end{array}$ & $\begin{array}{l}0.022 * * * \\
(0.004)\end{array}$ \\
\hline Maturity (years) & -- & -- & $\begin{array}{l}0.003 * * * \\
(0.001)\end{array}$ & $\begin{array}{l}0.002 * * * \\
(0.000)\end{array}$ & $\begin{array}{l}0.005^{* * * *} \\
(0.001)\end{array}$ \\
\hline Private equity-owned issuer & -- & -- & $\begin{array}{l}0.008 * * \\
(0.003)\end{array}$ & $\begin{array}{l}0.002 \\
(0.002)\end{array}$ & $\begin{array}{l}0.022 * * * \\
(0.008)\end{array}$ \\
\hline LBO funding & -- & -- & $\begin{array}{l}0.016 * * * \\
(0.006)\end{array}$ & $\begin{array}{l}0.001 \\
(0.003)\end{array}$ & $\begin{array}{l}0.050 * * * \\
(0.016)\end{array}$ \\
\hline Non-amortizing loan & -- & -- & $\begin{array}{l}0.089 * * * \\
(0.011)\end{array}$ & $\begin{array}{l}0.048 * * * \\
(0.011)\end{array}$ & $\begin{array}{l}0.108 * * * \\
(0.014)\end{array}$ \\
\hline $\begin{array}{l}\text { Fixed effects: } \\
\text { Year-month }\end{array}$ & $\mathrm{N}$ & Y & Y & $\mathrm{Y}$ & Y \\
\hline $\begin{array}{l}\text { Obs. } \\
R \text {-squared }\end{array}$ & $\begin{array}{l}14,312 \\
0.11\end{array}$ & $\begin{array}{l}14,312 \\
0.15\end{array}$ & $\begin{array}{l}14,031 \\
0.19\end{array}$ & $\begin{array}{l}9,429 \\
0.19\end{array}$ & $\begin{array}{l}4,881 \\
0.23\end{array}$ \\
\hline
\end{tabular}

Notes: This table presents regression of the incidence of cov-lite provisions on loan characteristics, estimated using a linear model. Each observation is a non-investment grade loan issued between 2001 and 2014. The dependent variable is a dummy equal to 1 if the loan is cov-lite and 0 otherwise. The independent variables include characteristics of the loan, the issuer, and the lending syndicate. The variables measuring the number of mutual funds and CLOs in the loan syndicate are both capped at 20. Errors are clustered by issuer.

*** Significant at the 1 percent level.

** Significant at the 5 percent level.

* Significant at the 10 percent level. 
TABLE 5 - CROSS-SECTIONAL RESULTS (AMOUNTS PURCHASED AT ISSUE)

Dependent variable:

Sample:

Share of MFs in syndicate

Share of CLOs in syndicate

Syndicate: Number of MFs

Syndicate: Number of CLOs

Loan size (million USD)

Maturity (years)

Private equity-owned issuer

LBO funding

Non-amortizing loan

Fixed effects:

Year-month

Obs.

$R$-squared
Incidence of cov-lite provisions

\begin{tabular}{|c|c|c|c|c|c|}
\hline (1) & (2) & (3) & (4) & $(5)$ & (6) \\
\hline & & & $\begin{array}{l}\text { Below } \\
\$ 100 \mathrm{~m}\end{array}$ & $\begin{array}{l}\$ 100 \mathrm{~m} \text { or } \\
\text { larger }\end{array}$ & \\
\hline $0.617 * * *$ & $0.590 * * *$ & $0.567 * * *$ & $0.418 * * *$ & $0.746 * * *$ & 0.163 \\
\hline$(0.163)$ & $(0.157)$ & $(0.153)$ & $(0.154)$ & $(0.231)$ & $(0.118)$ \\
\hline $0.527 * * *$ & $0.388 * * *$ & $0.330 * * *$ & $0.308 * * *$ & $0.686^{* *}$ & 0.016 \\
\hline$(0.141)$ & $(0.137)$ & $(0.130)$ & $(0.120)$ & $(0.283)$ & $(0.121)$ \\
\hline-- & -- & -- & -- & -- & $\begin{array}{l}0.014 * * * \\
(0.006)\end{array}$ \\
\hline -- & -- & -- & -- & -- & $\begin{array}{l}0.015 * * * \\
(0.004)\end{array}$ \\
\hline -- & -- & $\begin{array}{l}0.009 \text { **** } \\
(0.001)\end{array}$ & $\begin{array}{l}0.003 * * * \\
(0.000)\end{array}$ & $\begin{array}{l}0.006 * * * \\
(0.001)\end{array}$ & $\begin{array}{l}0.006 * * * \\
(0.001)\end{array}$ \\
\hline-- & -- & $\begin{array}{l}0.004 * * * \\
(0.001)\end{array}$ & $\begin{array}{l}0.001 * * * \\
(0.000)\end{array}$ & $\begin{array}{l}0.006 * * * \\
(0.001)\end{array}$ & $\begin{array}{l}0.003 * * * \\
(0.001)\end{array}$ \\
\hline-- & -- & $\begin{array}{l}0.008 * * \\
(0.003)\end{array}$ & $\begin{array}{l}0.001 \\
(0.002)\end{array}$ & $\begin{array}{l}0.023 * * * \\
(0.008)\end{array}$ & $\begin{array}{l}0.006^{*} \\
(0.003)\end{array}$ \\
\hline -- & -- & $\begin{array}{l}0.018 * * * \\
(0.006)\end{array}$ & $\begin{array}{l}0.004 \\
(0.003)\end{array}$ & $\begin{array}{l}0.052 * * * \\
(0.016)\end{array}$ & $\begin{array}{l}0.018 \text { **** } \\
(0.006)\end{array}$ \\
\hline -- & -- & $\begin{array}{l}0.094 * * * \\
(0.011)\end{array}$ & $\begin{array}{l}0.054 * * * \\
(0.011)\end{array}$ & $\begin{array}{l}0.052 * * * \\
(0.016)\end{array}$ & $\begin{array}{l}0.087 * * * \\
(0.010)\end{array}$ \\
\hline $\mathrm{N}$ & $\mathrm{Y}$ & $\mathrm{Y}$ & Y & $\mathrm{Y}$ & $\mathrm{Y}$ \\
\hline 14,313 & 14,313 & 14,310 & 9,429 & 4,881 & 14,313 \\
\hline 0.05 & 0.10 & 0.17 & 0.14 & 0.20 & 0.19 \\
\hline
\end{tabular}

Notes: This table presents a regression of the incidence of cov-lite provisions on loan characteristics, estimated using a linear model. Each observation is a non-investment grade loan issued between 2001 and 2014. The dependent variable is a dummy equal to 1 if the loan is cov-lite and 0 otherwise. The independent variables include characteristics of the loan, the issuer, and the lending syndicate. The share of mutual funds and CLOs are measured in dollar terms in at loan issuance. Errors are clustered by issuer.

*** Significant at the 1 percent level.

** Significant at the 5 percent level.

* Significant at the 10 percent level. 
TABLE 6 - CROSS-SECTIONAL RESULTS WITH DISAGREEMENT INDICATOR

\begin{tabular}{|c|c|c|c|}
\hline \multirow[t]{2}{*}{ Dependent variable: } & \multicolumn{3}{|c|}{ Incidence of cov-lite provisions } \\
\hline & (1) & $(2)$ & (3) \\
\hline \multicolumn{4}{|l|}{ Sample: } \\
\hline Share of MFs in syndicate & $\begin{array}{l}0.467 * * * \\
(0.151)\end{array}$ & $\begin{array}{l}0.462 * * * \\
(0.143)\end{array}$ & $\begin{array}{l}0.415^{* * *} \\
(0.134)\end{array}$ \\
\hline Share of CLOs in syndicate & $\begin{array}{l}0.464 * * * \\
(0.138)\end{array}$ & $\begin{array}{l}0.341 * * \\
(0.136)\end{array}$ & $\begin{array}{l}0.301 * * \\
(0.127)\end{array}$ \\
\hline MF - CLO disagreement (indicator) & $\begin{array}{l}0.320 * * \\
(0.108)\end{array}$ & $\begin{array}{l}0.277 * * \\
(0.111)\end{array}$ & $\begin{array}{l}0.258 * * \\
(0.111)\end{array}$ \\
\hline Loan size (million USD) & -- & -- & $\begin{array}{l}0.008 * * * \\
(0.001)\end{array}$ \\
\hline Maturity (years) & -- & -- & $\begin{array}{l}0.004 * * * \\
(0.001)\end{array}$ \\
\hline Private equity-owned issuer & -- & -- & $\begin{array}{l}0.007 * * \\
(0.003)\end{array}$ \\
\hline LBO funding & -- & -- & $\begin{array}{l}0.018 * * * \\
(0.006)\end{array}$ \\
\hline Non-amortizing loan & -- & -- & $\begin{array}{l}0.093 \text { *** } \\
(0.010)\end{array}$ \\
\hline $\begin{array}{l}\text { Fixed effects: } \\
\text { Year-month }\end{array}$ & $\mathrm{N}$ & Y & Y \\
\hline $\begin{array}{l}\text { Obs. } \\
R \text {-squared }\end{array}$ & $\begin{array}{l}14,312 \\
0.07\end{array}$ & $\begin{array}{l}14,312 \\
0.12\end{array}$ & $\begin{array}{l}14,310 \\
0.17\end{array}$ \\
\hline
\end{tabular}

Notes: This table presents a regression of the incidence of cov-lite provisions on loan characteristics, estimated using a linear model, and is similar to table 5. Each observation is a non-investment grade loan issued between 2001 and 2014. The dependent variable is a dummy equal to 1 if the loan is cov-lite and 0 otherwise. The independent variables include characteristics of the loan, the issuer, and the lending syndicate. The share of mutual funds and CLOs are measured in dollar terms in at loan issuance. The conflict indicator takes the value 1 if mutual funds and CLOs have total vote shares that are within a factor of two of each other, and they jointly own $10 \%$ or more of the loan. The conflict indicator takes the value 1 if mutual funds and CLOs have total vote shares that are within a factor of two of each other, and they jointly own $10 \%$ or more of the loan. Errors are clustered by issuer.

*** Significant at the 1 percent level.

** Significant at the 5 percent level.

* Significant at the 10 percent level. 
TABLE 7 - CROSS-Fund RESUlTS: SIZE AND COV-LITE SHARE

\begin{tabular}{|c|c|c|c|c|c|c|}
\hline \multirow[t]{2}{*}{ Dependent variable: } & \multicolumn{6}{|c|}{ Cov-lite share of fund holdings } \\
\hline & (1) & (2) & (3) & (4) & (5) & (6) \\
\hline Sample: & All & All & All & All & Open-end & Closed-end \\
\hline Log of assets under management & $\begin{array}{c}-0.0004 \\
(0.0017)\end{array}$ & $\begin{array}{l}-0.0002 \\
(0.0014)\end{array}$ & $\begin{array}{c}0.0134 * * * \\
(0.0024)\end{array}$ & $\begin{array}{c}0.0047 * * \\
(0.0023)\end{array}$ & $\begin{array}{c}0.0000 \\
(0.0019)\end{array}$ & $\begin{array}{c}-0.0043 \\
(0.0044)\end{array}$ \\
\hline Log of number of holdings & $\begin{array}{c}0.0108 * * * \\
(0.0016)\end{array}$ & $\begin{array}{c}0.0058 * * * \\
(0.0016)\end{array}$ & $\begin{array}{c}0.0154^{* * * *} \\
(0.0026)\end{array}$ & $\begin{array}{c}0.0035 \\
(0.0022)\end{array}$ & $\begin{array}{c}0.0093 * * * \\
(0.0022)\end{array}$ & $\begin{array}{c}0.0136^{* * * *} \\
(0.0017)\end{array}$ \\
\hline \multicolumn{7}{|l|}{ Fixed effects: } \\
\hline Year-quarter & - & Yes & - & Yes & - & - \\
\hline Mutual fund & - & - & Yes & Yes & - & - \\
\hline Obs. & 830 & 830 & 830 & 830 & 495 & 335 \\
\hline$R$-squared & 0.15 & 0.48 & 0.53 & 0.70 & 0.11 & 0.24 \\
\hline
\end{tabular}

Notes: This table presents a regression of the cov-lite loan holdings of mutual funds. Each observation is a quarterly observation of a mutual fund's loan holdings. The sample period is 2010:Q1-2014:Q4. The last column indicates independent variable means and standard deviations.

The dependent variable is either a dummy indicating whether a loan is amortizing (1) or bullet (0); or a continuous variable measuring loan maturity (in years). The independent variables include characteristics of the loan, the issuer, and the lending syndicate. The share of mutual funds and CLOs are measured in dollar terms in at loan issuance. Errors are clustered by mutual fund.

*** Significant at the 1 percent level.

** Significant at the 5 percent level.

* Significant at the 10 percent level. 
TABLE 8 - LOAN FEATURES REGULATING LENDER CONTROL

\begin{tabular}{|c|c|c|c|c|}
\hline \multirow[t]{2}{*}{ Dependent variable: } & \multicolumn{2}{|c|}{ Non-amortizing loan } & \multicolumn{2}{|c|}{ Maturity } \\
\hline & (1) & (2) & (3) & $(4)$ \\
\hline Share of MFs in syndicate & $\begin{array}{l}0.220 \\
(0.152)\end{array}$ & $\begin{array}{l}0.133^{*} \\
(0.076)\end{array}$ & $\begin{array}{l}4.174 * * * \\
(0.829)\end{array}$ & $\begin{array}{l}3.363 * * * \\
(0.420)\end{array}$ \\
\hline Share of CLOs in syndicate & $\begin{array}{l}0.408^{* * * *} \\
(0.135)\end{array}$ & $\begin{array}{l}0.276^{* * *} \\
(0.095)\end{array}$ & $\begin{array}{l}1.164 * * \\
(0.487)\end{array}$ & $\begin{array}{l}0.766^{*} \\
(0.441)\end{array}$ \\
\hline Loan size (million USD) & -- & $\begin{array}{l}0.039 * * * \\
(0.002)\end{array}$ & -- & $\begin{array}{l}0.160 * * * \\
(0.018)\end{array}$ \\
\hline Maturity (years) & -- & $\begin{array}{l}0.007 * * * \\
(0.002)\end{array}$ & -- & -- \\
\hline Private equity-owned issuer & -- & $\begin{array}{l}0.007 \\
(0.008)\end{array}$ & -- & $\begin{array}{l}0.584 * * * \\
(0.049)\end{array}$ \\
\hline LBO funding & -- & $\begin{array}{l}-0.051 * * * \\
(0.009)\end{array}$ & -- & $\begin{array}{l}0.775^{* * * *} \\
(0.063)\end{array}$ \\
\hline Non-amortizing loan & -- & -- & -- & $\begin{array}{l}0.302 * * * \\
(0.080)\end{array}$ \\
\hline $\begin{array}{r}\text { Fixed effects: } \\
\text { Year-month }\end{array}$ & $\mathrm{Y}$ & $\mathrm{Y}$ & $\mathrm{Y}$ & $\mathrm{Y}$ \\
\hline $\begin{array}{l}\text { Obs. } \\
R \text {-squared }\end{array}$ & $\begin{array}{l}14,313 \\
0.05\end{array}$ & $\begin{array}{l}14,310 \\
0.05\end{array}$ & $\begin{array}{l}14,313 \\
0.08\end{array}$ & $\begin{array}{l}14,310 \\
0.14\end{array}$ \\
\hline
\end{tabular}

Notes: This table presents a regression of the incidence of cov-lite provisions on loan characteristics, estimated using a linear model. Each observation is a non-investment grade loan issued between 2001 and 2014. The dependent variable is either a dummy indicating whether a loan is amortizing (1) or bullet (0); or a continuous variable measuring loan maturity (in years). The independent variables include characteristics of the loan, the issuer, and the lending syndicate. The share of mutual funds and CLOs are measured in dollar terms in at loan issuance. Errors are clustered by issuer.

*** Significant at the 1 percent level.

** Significant at the 5 percent level.

* Significant at the 10 percent level. 
TABLE 9 - COVENANT TIGHTNESS

\begin{tabular}{|c|c|c|c|c|}
\hline \multirow[t]{2}{*}{ Dependent variable: } & \multicolumn{4}{|c|}{ Covenant index } \\
\hline & (1) & (2) & (3) & (4) \\
\hline Share of MFs in syndicate & -- & -- & $\begin{array}{l}-0.257 \\
(1.557)\end{array}$ & $\begin{array}{l}0.475 \\
(1.148)\end{array}$ \\
\hline Share of CLOs in syndicate & -- & -- & $\begin{array}{l}0.751 \\
(1.648)\end{array}$ & $\begin{array}{l}-0.051 \\
(1.213)\end{array}$ \\
\hline Cov lite indicator & $\begin{array}{l}0.015 \\
(0.220)\end{array}$ & $\begin{array}{l}0.039 \\
(0.307)\end{array}$ & -- & -- \\
\hline Loan size (million USD) & -- & $\begin{array}{l}-0.039 \\
(0.049)\end{array}$ & -- & $\begin{array}{l}-0.034 \\
(0.051)\end{array}$ \\
\hline Maturity (years) & -- & $\begin{array}{l}-0.039 \\
(0.041)\end{array}$ & -- & $\begin{array}{l}-0.048 \\
(0.037)\end{array}$ \\
\hline Private equity-owned issuer & -- & $\begin{array}{l}0.039 \\
(0.188)\end{array}$ & -- & $\begin{array}{l}0.152 \\
(0.174)\end{array}$ \\
\hline LBO funding & -- & $\begin{array}{l}-0.415^{*} \\
(0.237)\end{array}$ & -- & $\begin{array}{l}-0.510^{* *} \\
(0.240)\end{array}$ \\
\hline Non-amortizing loan & -- & $\begin{array}{l}0.294 \\
(0.209)\end{array}$ & -- & $\begin{array}{l}0.217 \\
(0.185)\end{array}$ \\
\hline $\begin{array}{l}\text { Fixed effects: } \\
\text { Year-month }\end{array}$ & Y & Y & $\mathrm{Y}$ & $\mathrm{Y}$ \\
\hline $\begin{array}{l}\text { Obs. } \\
R \text {-squared }\end{array}$ & $\begin{array}{l}355 \\
0.68\end{array}$ & $\begin{array}{l}329 \\
0.66\end{array}$ & $\begin{array}{l}347 \\
0.70\end{array}$ & $\begin{array}{l}329 \\
0.70\end{array}$ \\
\hline
\end{tabular}

Notes: This table presents a regression of an index of covenant strength, based on classifications done by XTRACT Research, the composition of the loan syndicate, the incidence of cov-lite provisions, and various other loan characteristics, using a linear model. Each observation is a non-investment grade loan issued between 2001 and 2014. The independent variables include characteristics of the loan, the issuer, and the lending syndicate. The share of mutual funds and CLOs are measured in dollar terms in at loan issuance. Errors are clustered by issuer.

*** Significant at the 1 percent level.

** Significant at the 5 percent level.

* Significant at the 10 percent level. 


\section{Earlier Working Papers:}

For a complete list of Working Papers published by Sveriges Riksbank, see www.riksbank.se

Estimation of an Adaptive Stock Market Model with Heterogeneous Agents

Some Further Evidence on Interest-Rate Smoothing: The Role of Measurement Errors in the Output Gap

by Mikael Apel and Per Jansson

Bayesian Estimation of an Open Economy DSGE Model with Incomplete Pass-Through

by Malin Adolfson, Stefan Laséen, Jesper Lindé and Mattias Villani

Are Constant Interest Rate Forecasts Modest Interventions? Evidence from an Estimated Open Economy

DSGE Model of the Euro Area

by Malin Adolfson, Stefan Laséen, Jesper Lindé and Mattias Villani

Inference in Vector Autoregressive Models with an Informative Prior on the Steady State

by Mattias Villani

Bank Mergers, Competition and Liquidity

2005:182

by Elena Carletti, Philipp Hartmann and Giancarlo Spagnolo

Testing Near-Rationality using Detailed Survey Data

by Michael F. Bryan and Stefan Palmqvist

Exploring Interactions between Real Activity and the Financial Stance

2005:184

by Tor Jacobson, Jesper Lindé and Kasper Roszbach

Two-Sided Network Effects, Bank Interchange Fees, and the Allocation of Fixed Costs

2005:185

by Mats $A$. Bergman

Trade Deficits in the Baltic States: How Long Will the Party Last?

2005:186

by Rudolfs Bems and Kristian Jönsson

Real Exchange Rate and Consumption Fluctuations follwing Trade Liberalization

by Kristian Jönsson

Modern Forecasting Models in Action: Improving Macroeconomic Analyses at Central Banks

by Malin Adolfson, Michael K. Andersson, Jesper Lindé, Mattias Villani and Anders Vredin

Bayesian Inference of General Linear Restrictions on the Cointegration Space

2005:189

by Mattias Villani

Forecasting Performance of an Open Economy Dynamic Stochastic General Equilibrium Model

2005:190

by Malin Adolfson, Stefan Laséen, Jesper Lindé and Mattias Villani

Forecast Combination and Model Averaging using Predictive Measures

2005:191

by Jana Eklund and Sune Karlsson

Swedish Intervention and the Krona Float, 1993-2002

2006:192

by Owen F. Humpage and Javiera Ragnartz

A Simultaneous Model of the Swedish Krona, the US Dollar and the Euro

2006:193

by Hans Lindblad and Peter Sellin

Testing Theories of Job Creation: Does Supply Create Its Own Demand?

2006:194

by Mikael Carlsson, Stefan Eriksson and Nils Gottfries

Down or Out: Assessing The Welfare Costs of Household Investment Mistakes

2006:195

by Laurent E. Calvet, John Y. Campbell and Paolo Sodini

Efficient Bayesian Inference for Multiple Change-Point and Mixture Innovation Models

2006:196

by Paolo Giordani and Robert Kohn

Derivation and Estimation of a New Keynesian Phillips Curve in a Small Open Economy

2006:197

by Karolina Holmberg

Technology Shocks and the Labour-Input Response: Evidence from Firm-Level Data

2006:198

by Mikael Carlsson and Jon Smedsaas

Monetary Policy and Staggered Wage Bargaining when Prices are Sticky

2006:199

by Mikael Carlsson and Andreas Westermark

The Swedish External Position and the Krona

by Philip R. Lane 
Using a New Open Economy Macroeconomics model to make real nominal exchange rate forecasts 
Evaluating Microfoundations for Aggregate Price Rigidities: Evidence from Matched Firm-Level Data on

Flexible Modeling of Conditional Distributions Using Smooth Mixtures of Asymmetric

Student T Densities

by Feng Li, Mattias Villani and Robert Kohn

Forecasting Macroeconomic Time Series with Locally Adaptive Signal Extraction

Risk Premiums and Macroeconomic Dynamics in a Heterogeneous Agent Model by Ferre De Graeve, Maarten Dossche, Marina Emiris, Henri Sneessens and Raf Wouters

Picking the Brains of MPC Members

by Mikael Apel, Carl Andreas Claussen and Petra Lennartsdotter

Involuntary Unemployment and the Business Cycle

by Lawrence J. Christiano, Mathias Trabandt and Karl Walentin

Housing collateral and the monetary transmission mechanism

by Karl Walentin and Peter Sellin

The Discursive Dilemma in Monetary Policy

by Carl Andreas Claussen and Øistein Røisland

Monetary Regime Change and Business Cycles

Bayesian Inference in Structural Second-Price common Value Auctions

by Bertil Wegmann and Mattias Villani

Equilibrium asset prices and the wealth distribution with inattentive consumers

by Luca Sala, Ulf Söderström and Antonella Trigari

Density-Conditional Forecasts in Dynamic Multivariate Models

by Michael K. Andersson, Stefan Palmqvist and Daniel F. Waggoner

Anticipated Alternative Policy-Rate Paths in Policy Simulations

by Stefan Laséen and Lars E. O. Svensson

MOSES: Model of Swedish Economic Studies

by Gunnar Bårdsen, Ard den Reijer, Patrik Jonasson and Ragnar Nymoen

The Effects of Endogenuos Firm Exit on Business Cycle Dynamics and Optimal Fiscal Policy

by Lauri Vilmi

Parameter Identification in a Estimated New Keynesian Open Economy Model 
The Cost of Consumer Payments in Sweden

by Björn Segendorf and Thomas Jansson

Trade Credit and the Propagation of Corporate Failure: An Empirical Analysis

by Tor Jacobson and Erik von Schedvin

Structural and Cyclical Forces in the Labor Market During the Great Recession: Cross-Country Evidence

by Luca Sala, Ulf Söderström and AntonellaTrigari

Pension Wealth and Household Savings in Europe: Evidence from SHARELIFE

by Rob Alessie, Viola Angelini and Peter van Santen

Long-Term Relationship Bargaining

by Andreas Westermark

Using Financial Markets To Estimate the Macro Effects of Monetary Policy: An Impact-Identified FAVAR*

by Stefan Pitschner

DYNAMIC MIXTURE-OF-EXPERTS MODELS FOR LONGITUDINAL AND DISCRETE-TIME SURVIVAL DATA

by Matias Quiroz and Mattias Villani

Conditional euro area sovereign default risk

by André Lucas, Bernd Schwaab and Xin Zhang

Nominal GDP Targeting and the Zero Lower Bound: Should We Abandon Inflation Targeting?*

by Roberto M. Billi

Un-truncating VARs*

by Ferre De Graeve and Andreas Westermark

Housing Choices and Labor Income Risk

by Thomas Jansson

Identifying Fiscal Inflation*

by Ferre De Graeve and Virginia Queijo von Heideken

On the Redistributive Effects of Inflation: an International Perspective*

by Paola Boel

Business Cycle Implications of Mortgage Spreads*

by Karl Walentin

Approximate dynamic programming with post-decision states as a solution method for dynamic

by Christoph Bertsch

Distortionary Fiscal Policy and Monetary Policy Goals 
by Karolina Holmberg

A wake-up call: information contagion and strategic uncertainty

by Toni Ahnert and Christoph Bertsch

Debt Dynamics and Monetary Policy: A Note

by Stefan Laséen and Ingvar Strid

Optimal taxation with home production

by Conny Olovsson

Incompatible European Partners? Cultural Predispositions and Household Financial Behavior

by Michael Haliassos, Thomas Jansson and Yigitcan Karabulut

How Subprime Borrowers and Mortgage Brokers Shared the Piecial Behavior

by Antje Berndt, Burton Hollifield and Patrik Sandàs

The Macro-Financial Implications of House Price-Indexed Mortgage Contracts

by Isaiah Hull

Does Trading Anonymously Enhance Liquidity?

by Patrick J. Dennis and Patrik Sandås

Systematic bailout guarantees and tacit coordination

by Christoph Bertsch, Claudio Calcagno and Mark Le Quement

Selection Effects in Producer-Price Setting

by Mikael Carlsson

Dynamic Demand Adjustment and Exchange Rate Volatility

by Vesna Corbo

Forward Guidance and Long Term Interest Rates: Inspecting the Mechanism

by Ferre De Graeve, Pelin Ilbas \& Raf Wouters

Firm-Level Shocks and Labor Adjustments

by Mikael Carlsson, Julián Messina and Oskar Nordström Skans

A wake-up call theory of contagion

by Toni Ahnert and Christoph Bertsch

Risks in macroeconomic fundamentals and excess bond returns predictability

by Rafael B. De Rezende

The Importance of Reallocation for Productivity Growth: Evidence from European and US Banking

by Matias Quiroz, Mattias Villani and Robert Kohn

Amortization Requirements and Household Indebtedness: An Application to Swedish-Style Mortgages

by Isaiah Hull

Fuel for Economic Growth?

by Johan Gars and Conny Olovsson

Searching for Information

by Jungsuk Han and Francesco Sangiorgi

What Broke First? Characterizing Sources of Structural Change Prior to the Great Recession

Price Level Targeting and Risk Management

by Roberto Billi

Central bank policy paths and market forward rates: A simple model

by Ferre De Graeve and Jens Iversen

Jump-Starting the Euro Area Recovery: Would a Rise in Core Fiscal Spending Help the Periphery? 
by Daria Finocchiaro, Giovanni Lombardo, Caterina Mendicino and Philippe Weil

Fire Sale Bank Recapitalizations

by Christoph Bertsch and Mike Mariathasan

Since you're so rich, you must be really smart: Talent and the Finance Wage Premium

by Michael Böhm, Daniel Metzger and Per Strömberg

Debt, equity and the equity price puzzle

by Daria Finocchiaro and Caterina Mendicino

Trade Credit: Contract-Level Evidence Contradicts Current Theories

by Tore Ellingsen, Tor Jacobson and Erik von Schedvin

Double Liability in a Branch Banking System: Historical Evidence from Canada

by Anna Grodecka and Antonis Kotidis

Subprime Borrowers, Securitization and the Transmission of Business Cycles

Real-Time Forecasting for Monetary Policy Analysis: The Case of Sveriges Riksbank

by Jens Iversen, Stefan Laséen, Henrik Lundvall and Ulf Söderström

Fed Liftoff and Subprime Loan Interest Rates: Evidence from the Peer-to-Peer Lending

by Christoph Bertsch, Isaiah Hull and Xin Zhang

Curbing Shocks to Corporate Liquidity: The Role of Trade Credit

by Niklas Amberg, Tor Jacobson, Erik von Schedvin and Robert Townsend

Firms' Strategic Choice of Loan Delinquencies 
Sveriges Riksbank

Visiting address: Brunkebergs torg 11

Mail address: se-103 37 Stockholm

Website: www.riksbank.se

SVERIGES Telephone: +46 878700 00, Fax: +46 8210531

RIKSBANK E-mail: registratorn@riksbank.se 